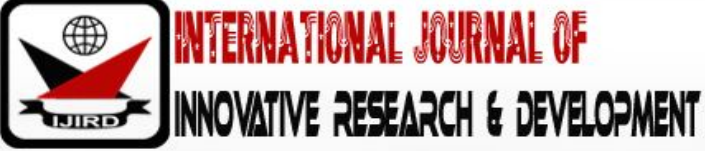

ISSN 2278 - 0211 (Online)

\section{EFL Learners' Autunomy in Learning English Vis-A-Vis Teachers' Role in the Development of Learner Autonomy}

\author{
Chernet Zerga Wejira \\ Lecturer, Department of English Language and Literature, Welkite University, Ethiopia
}

\begin{abstract}
:
The purpose of this study was to examine grade twelve students' and their teachers' perception and practice in the development of learner autonomy at Emdibr Preparatory School. To achieve this purpose, descriptive survey method was employed. Simple random sampling was used to select 112 subjects out of 398 student population. The obtained data were analyzed by employing statistical tools such as frequency, percentage, mean, Chi-square and independent sample t-test using SPSS window 15 software. Participants' responses show that students did not seem to exert effort in involving autonomous learning activities. Similarly, the teachers do not seem to encourage learners to do these activities and tasks by themselves. On the other hand, there is no significant difference in students and teachers perception of taking responsibility. Independent sample t-test between teachers' and students' perception of students' ability in language learning is $3.34, \mathrm{p}=0.00$. Concerning language learning strategy use students and teachers usually employ cognitive strategies. Teachers rarely employ monitoring and evaluation strategies in their instruction. English language teachers are recommended to be aware of the value of independent language learning, to be prepared to assume new roles in the classroom, to prepare autonomous learning contents and tasks in their instructions. They should provide learners with choice based on their needs and involve them in decision-making in their learning so that their motivation is enhanced.
\end{abstract}

Keywords: Autonomy, readiness, learner responsibility, self-regulated learner, perception, autonomous learners

\section{Introduction}

\subsection{Background to the Study}

It is a commonly held belief that education is meant to bring about desirable behavioral changes in the learner in terms of knowledge, skills and attitude. It should, in the main, have the purpose of effecting durable outcomes on the target learners. Besides learning specific contents and acquiring skills that are relevant to certain fields, students need to be able to get, from their school experiences, the methods and techniques that help them become self -learners in their future studies and real life, too. These methods and techniques enable learners to develop autonomy in acquiring further knowledge and understanding. In connection with this, the following quote is worth noting: "The value of education resides not alone in the knowledge which has been acquired, but even more, in the skills which give students independence in expanding further knowledge and understanding" (Blue, 1988: 129).Over the last twenty years and as a consequence of the changed views in the field of English Language Teaching, a great emphasis has been put on the role of learners (Dickinson, 1989; Tudor, 1993). That is, language teachers started to put students at the center of class room organization respecting their needs, strategies and styles. This resulted in the emergence of the notion of learner-centered education which views language learning as a collaborative process between teachers and learners rather than a set of rules to be transferred to the learners from teachers. According to Tudor (1993) learner-centeredness is not a method, nor may it be decreased to a set of rules. However, it is an approach, which views students to have more active and participatory roles in the learning process than in traditional approaches.

This new perspective of learner-centeredness has changed the roles of learners and teachers in the classroom. In today's language classroom, learners are expected to take more responsibility for their own learning, and teachers are expected to help learners become more independent inside and outside the classroom. These developments have brought the concept of "learner autonomy" in the field of language teaching (Aoki, 1999;Benson, 2001). In a learner-centered classroom, the curriculum involves learners in some ways. According to Nunan (1989), in a learner- centered classroom teachers and learners will work collaboratively for the curriculum development and learners will be allowed to make decisions on content selection, methodology and evaluation. Nunan (1996) also discusses the two complementary aims of learner-centered class rooms. One of them focuses on language content, the other focuses on learning process. 
He adds that throughout the achievement of these aims, learners need to decide what they want to learn and how they want to learn. In this phase, it is the teacher's duty to create such conditions in which they educate students in the skills and knowledge they require while making choices about the process and content of their learning. Tudor (1993) has suggested that if teachers were to create those conditions, students will be able to benefit most from the teaching and learning process, particularly in the following areas: (a) more relevant goal setting with the contributions of students, (b) more effective learning enriched with students' preferences, (c) more benefit from activities, the content of which decided by students, (d) more efficient study program with more student involvement.

Moreover, putting an emphasis on the learner in a foreign language learning process has been the greatest possible importance for some approaches. One of them is communicative language teaching (CLT), which emerged with the changed views on the nature of language learning in the 1970s and 1980s. The issue of learning how to learn, or developing autonomous learning skills has been recognized in language teaching circles, especially since the advent of the movement towards communicative language learning and teaching (Tudor, 1993; Sharp, 2002; Nunan, 1989).

According to (Wenden, 1991; Voller, 1997; Dickenson 1988), one useful effect of the movement towards more communicative language instruction has been the recognition given to the role the students play in the process of learning a language. In effect, the old belief that the teacher teaches and learners learn has never been influential as such and, as a result, there has been a shift of emphasis in classroom instruction, and research from the process of teaching to the process of learning. As Wenden further comments, this shift of attention needs a student- centered approach and participatory model of teaching. This prominent shift towards learner-centeredness in language education has led to the emergence of the concept of learner autonomy.

The concept of autonomy first entered the field of language teaching with adult self-directed learning and autonomy, defined as the capacity to take charge of one's own learning(Holec, cited in Little, 1991; Little wood, 19970). In self-directed learning, the objectives, progress and evaluation of learning were determined by learners themselves.

Fostering the development of learner autonomy rests on the pedagogical claim that in formal educational contexts, reflectivity and self-awareness produce better learning (Little, 1991; White, 1995; Voller,1997). Little, as cited by Mesfin (2008) summarizes the arguments in favor of learner autonomy in learning a language up in to two key points. First, if learners are reflectively involved in planning, monitoring and evaluating their learning, they learn more successfully than if the teacher does these on their behalf because in the former case, the learning becomes more meaningful, personal and focused, and second this reflective engagement in learning is likely to enable the students to effectively integrate the learnt input with their schematic knowledge.

The idea of learners' taking more responsibility in the learning process is supported for two reasons: learning can only be performed by learners themselves and learners need to gain the ability to carry on learning after formal education (Holec, 1981; Hedge, 1994; Little wood, 1999). Moreover, Little (1991) highlights that this responsibility involves taking the control in many processes which have traditionally belonged to the teacher such as deciding on learning objectives, selecting learning methods, evaluating and monitoring the learning process, etc. Learners become active participants accepting responsibility for their own learning. According to Benson and Voller (1997), this responsibility shift requires some changes in teachers' roles.

On the other hand, autonomous learners take control of their learning with the help of critical thinking skills and learning strategies. For example, some researchers (Wenden, 1991; White, 1995; Cotterall, 1999) mention the crucial role of using meta-cognitive strategies in autonomous learning. In the cognitive literature on learning, autonomous learning is referred to as self-regulation, and planning, monitoring and evaluating are commonly referred to as the three key strategies required for self-regulation

The recent literature abounds with studies that focus on promoting the necessary skills required for autonomous or self-regulated learning such as teaching students learning strategies, raising students' awareness on the learning process, increasing student involvement to help them become more self-regulated or autonomous(Dickenson, 1988;Lee, 1991; Benson and Voller,1997). All these concepts are related to teaching students how to think, how to learn and to take control over their learning.

To sum up, the traditional teaching methods requiring passive learning are not efficient to meet the demand of language learning, and that encouraging greater learner autonomy greatly assists students to learn efficiently and effectively (Holec, 1981; Wenden, 1991; White, 1995; Little wood, 1999). Developing autonomous learning is indispensable as the aim of all education is to help people think, act and learn independently in relevant areas of their lives. In this respect, a strategy for developing autonomy in language teaching and learning will require, among other things, enhanced willingness and readiness to take charge of learning, self-awareness to improve motivation and cognitive and metacognitive language learning strategies.

Therefore, it is necessary to research the participants' perception and practice oflearner autonomy. In order to find out whether students and teachers are ready for developing autonomy in learning English calls for a research

\subsection{Statement of the Problem}

In Ethiopia, where English is learned not as second language, but as foreign language, learners need to be autonomous because their environment provides few opportunities to actually use English in daily life. Learner autonomy has recently been gaining increasing popularity in language teaching circles as evidenced by the great emphasis it has received in the ELT literature. As Dornyei (2001) puts it, a great many books and articles have recently emphasized the role learner independence plays in producing effective and life- long language learners, by creating in them a sense of responsibility or duty-mindedness, which helps them to take the lion's share in their language study. It is often stressed that if students are committed to their learning, the problem of motivation is likely to be solved since autonomous learners 
can develop attitudinal conditions that can alleviate setbacks in motivation (Little wood, 1999). It is with this rationale that Brookes and Grund (1988:1) firmly argue in favor of autonomous language learning, saying, "It seems axiomatic that learner autonomy should be the goal of every learner and every teacher".

Learners need to participate in the teaching learning process to a great extent. They are expected to be responsible for their own learning before they join universities. Voller(1997) suggests that in learning cultures which are teacher centered there can be adjustment problem to amore student-centered approach. Voller also adds that when preparatory students' progress to tertiary level education, there can be difficulties. The learning process needs to shift from being passive to active: from teacher dependence to more learner independence. Concerning this, Dikenson (1988) states that universitylevel language learning involves higher, more demanding skills and tasks such as reading a novel, analyzing a poem or story, listening to lectures, or writing a research paper where learning independently is sought. Therefore, grade twelve students should be helped to practice autonomous learning practices.

There is a sound theoretical argument favoring learner autonomy in learning language. Learner autonomy leads to success in the language being learned (Scharle and Szabo 2000; Dornyei,2001;Onozowa, 2010). Involving students in decisions about learning goals, activities, materials, assignments, etc. means providing them with a share of the responsibility over their own language learning (Little, 1991). This opportunity enables them to evaluate the process and outcome of their language learning (Clark, 1978). Sharing responsibility on decision making process can help learners develop a sense of responsibility for their own learning, which is the basic component of learner autonomy.

Similarly, since the adoption of student-centered approach and communicative language teaching which require among other things, "training learners to monitor and assess themselves to be an emphasis on the subject of student freedom to participate actively in language learning, rather than being coerced only to act according to the teachers' wishes and preferences." (Scharle and Szabo, 2000:22). Particularly, it is taken for granted that high school English language teachers are aware of how to encourage students to become independent learners of the language.

The fact that there has been a shift in approach to the teaching and learning of English has not been a guarantee for the development of learner autonomy. There are symptoms that the situation in Ethiopian high schools is otherwise. Preparatory teachers, especially those who teach Grade Twelve English at Emdibir are often heard of complaining about their students' inclination to entirely rely on their teachers, considering the latter solely responsible for student success or failure.

On the other hand, in contexts in which the researcher works the teachers are still responsible for a list of management tasks such as selecting learning materials and topics, keeping records and evaluating progress, allocating time to tasks and so on. Moreover, from the point of view of learner autonomy, these tasks may be considered as diminishing students' perception of taking responsibility since the act of learning something must always be personal, individual act (Dickinson, 1989). But there is no independence and autonomy when at least some of the responsibilities specified are not vested in the students, but entrusted to the teachers.

In spite of its importance in facilitating learning, there appears to be a scarcity of local studies which strictly center on the subject of learner autonomy. The researcher has come across only four studies conducted by Addis Abeba University MA in TEFL students- Atakilt (1998); Teodros (2005); Nuru - razik (2006) and Mesfin (2008).

Although the above researches were conducted on different institutions of learning and levels other than grade 12, generally concentrated on autonomy in learning English they had different aims. Atakilt's study was carried out on Addis Abeba university freshman students and their English language instructors. This study was aimed at finding out whether or not English language instructors who taught freshman students incorporated components of learning strategy training in their instruction and indicated that the said instructors did not sufficiently include strategy training inputs in their lessons. Teodros' research attempted to investigate the role played by English language teachers at unity University College in Addis Abeba to promote independent learning, and came up with a conclusion that generally pinpointed teachers' deficiencies in this regard. Nuru-razik focused on the practice of autonomous language learning among third year English department students at Bahir Dar University. His study showed that students' use of autonomous learning strategy was characterized with variations from one strategy to another with maximum awareness and use of meta-cognitive strategy. Finally, the research undertaken by Mesfin to examine the practice of autonomous learning by grade eleven students at Mekele Atse Yohannes Preparatory School concluded that students were found ineffective in terms of taking charge of their learning.

The major difference between the present study and the afore-mentioned local studies is the fact that none of them has studied learner autonomy vis-à-vis teachers' readiness to promote learner autonomy. The above-mentioned studies did not incorporate students' and teachers' perception of responsibility and ability which is an important aspect of autonomy development. While most of them were studied in universities, this study is conducted on high school students. However, there is similarity between the above studies and this study. All of them included autonomous learning practices, to varying degree, that learners employ to take control of their learning. However, none of the above studies related learner autonomy in relation to what teachers do to promote learner autonomy.

Learner autonomy can be promoted not only by the students' readiness but also by the teachers' readiness and commitment to develop it. It equally requires the teachers' awareness and effort. The teacher and students should work together for the same goal, producing independent learner. However, if the teachers' practices and views in language learning do not relate in any degree, it would be very difficult to achieve autonomy in learning language. Furthermore, as it has been indicated earlier there is a scarcity of researches conducted on learner autonomy. That means, even though the learners are poor to take control of their learning by themselves, there is knowledge gap on how to develop learner 
autonomy on the grade level in focus. Thus, this study was partially a reaction to this situation. It tried to achieve to answer the research questions and achieve the objectives that follow them.

\subsection{Research Questions}

The study will try to answer the following research questions:

- Do grade twelve students and EFL teachers at Emdibir Preparatory School practice autonomous language learning activities in the teaching -learning process?

- Is there a significant difference between students' and EFL teachers' perceptions of learner autonomy (responsibility and ability perception) in learning English at Emdibir Preparatory School?

- Do the students and EFL teachers employ language learning strategies (cognitive and meta-cognitive strategies) in the teaching-learning process at the school in focus?

\subsection{Objectives of the Study}

\subsubsection{General Objectives of the Study}

The main intent of this study is to investigate students' and teachers' perception and practice of learner autonomy at Emdebir Preparatory School.

\subsubsection{Specific Objectives of the Study}

The study has specific objectives given below

- The study intends to assess whether grade twelve students and teachers at Emdibir Preparatory School use autonomous learning activities in the teaching -learning process.

- It investigates the difference in perceptions of learner autonomy (responsibility and ability perception)between students and teachers in learning English at Emdibir Preparatory School.

- It tries to find the language learning strategies (cognitive and meta-cognitive strategies) employed by students and teachers in the teaching-learning process at the school in focus.

\subsection{Significance of the Study}

This study is significant in various ways. First of all, it is believed that it can initiate English language teachers, especially those who teach grade twelve, to take practical actions to produce independent learners of the language by bringing the issue of learner autonomy to the attention of these teachers and helping them to revitalize their awareness of the matter. Secondly, it helps English language teachers to know the extent of their students' readiness to accept responsibility and take control of their learning before adopting learner training.Third, the study can benefit teachers who are likely to alert their learners into activities and practices pertinent to the development of autonomy in learning English. Furthermore, the study can be of help for syllabus designers and material writers to take into consideration the task of creating syllabuses and materials that are geared towards encouraging students to develop autonomous learning skills in studying English. It can serve as a preliminary idea for any interested researcher in the area.

\section{Research Methodology}

This chapter gives a brief account of the methodology employed in this research. It highlights the research design, population of the study, sampling technique, and data gathering instruments, procedure of data collection and the methods used in data analysis.

\subsection{Research Design}

This study employs a descriptive survey design, including both quantitative and qualitative techniques. Survey methodology is chosen since it provides a quantitative or numeric description of trends, attitudes, or opinions of a population by studying a sample of that population (Creswell, 2003). A survey is also suggested for examining the relationship between and among variables to answer questions and hypothesis. Therefore, it could be useful to describe the existing situation about students' and teachers' perception and practice in developing learner autonomy. In addition, this method, as Payne (2004) points out, is used to mix qualitative and quantitative methods in data collection and processing, that is, it adopts a mixed approach research design.

\subsection{Population of the Study}

The target population of the study is grade 12 students and teachers of Emdebir preparatory school. This school is selected purposively because of its proximity for the researcher. There were 398(246 males and 152 females) grade twelve students and 8 teachers in the school in 2003 E.C academic year. Grade 12 was chosen since building autonomy in learning at this level, and reinforcing it if it has already been established, will help students to adjust themselves with the preparatory class courses as well as courses in institutions of higher learning where learner autonomy is increasingly sought.

\subsection{Sampling}

Out of 398 students, 112 students (70males and 42female), 27.6\%, were selected using disproportionate stratified sampling technique to fill out the questionnaire. The students were selected from the eightsections (A, B, C, D, E, F, G, and $\mathrm{H})$ of grade 12. Based on the name lists of the students in each section 14 students were selected. Equal number of 
students in each section was drawn since the number of students in each section was similar (48-50 students). Secondly, six students were randomly selected among the one hundred and ten students to participate in the interview.On the other hand,all of grade 12 teachers (eight teachers) participated to fill out the questionnaire. That means comprehensive sampling was employed. Most scholars suggest including all the population in a study when the number of the population is too small (Kumar, 1996; Gay and Airasian, 1988; Creswell, 2003). Moreover, four teachers were randomly selected for class room observation.

\subsection{Data Collection Instruments}

To elicit the data from participants (students and teachers), the researcher used three data gathering methods. Namely: questionnaire, interview and classroom observation. Questionnaire and interview were chosen because questionnaire is believed to be a useful tool to gather data on a wide range of topics from a large number of respondents, while interview has the advantage of generating active face-to-face interaction between the researcher and the informant (Kumar, 1996).

\subsubsection{Questionnaire}

\subsubsection{Construction of the Questionnaire}

Questionnaire was designed to see grade twelve students' and teachers' perception and practice of learner autonomy at Emdebir Secondary School (See the questionnaire, pp., 86-89). Prior to the construction of the questionnaire, relevant literature was reviewed. For this purpose, the questionnaire was constructed to compare activities and tasks students involve in learning English autonomously and teachers' practices in promoting autonomy, students' and teachers' perception of each other's responsibilities, students' and teachers' perception of students' abilities, and cognitive and meta-cognitive strategies students and teachers employ in developing learner autonomy.

The rationale behind this compilation was that each section could be thought of as manifestations of autonomous language learning behavior. That is, when the relevant literature was searched for, it was inevitable to come across the relationship between learner autonomy and the areas mentioned above. For instance, Little wood (1996) states that learners' willingness to assume responsibility is the center of the notion of autonomy. Furthermore, Crabbe (1993) states the necessity of learners' using opportunities inside the classroom to attain success. Finally, in the cognitive literature on learning, autonomous learning is referred to as self-regulation, which requires students' use of three strategies: planning, monitoring, and evaluation. Zimmerman (1989) portrays a detailed picture of a self-regulated learner by stating that they are meta-cognitively active participants in their own learning process and they initiate and direct their own efforts to acquire knowledge and skill instead of relying on teachers or others.

\subsubsection{Pilot Study}

Before piloting, the first draft of the questionnaire was given to a friend who is a Master's student in the field of curriculum at AAU to evaluate the items in the questionnaire critically in terms of content validity, face validity and clarity of the items. Some items which were not directly related to the topic were discarded and appropriate correction was made. Then, the students' questionnaire was translated into Amharic with a friend, who earned second degree in Amharic since the questionnaire was taught to be difficult for the students to comprehend. After revising the first draft of the questionnaire, the Amharic version of the questionnaire, was piloted to the non-sample students of 22 students (20 percent of the actual sample size) with the intention of checking the effectiveness of the questionnaire and making improvements. Similarly, pilot study on teachers' questionnaire was conducted using three grade 12 teachers at Goro Preparatory School. The pilot study on teachers' questionnaire was conducted in other school since all of the grade 12 teachers in Emdebir Preparatory School were to be involved in the actual study. Following the pilot study, improvements were made in both questionnaires. Double-barreled questions, unclear instructions, ambiguous items and inadequate scales were improved. For example, items 15, 22 and 30 of the students' questionnaire which lacked clarity were revised. The participants involved in the pilot study were not included in the sample during the administration of the final form of the questionnaire. The grade 12 students and teachers involved in the pilot study were selected randomly.

In order to estimate the reliability of the questionnaires Cronbach's alpha was calculated for the internal consistency of the items. Cronbach's alpha measures internal consistency reliability by determining how all items on a test relate to all other test items and to the total items (Gay and Airasian, 1988). The results were 0.56 and 0.51 for students' and teachers' questionnaires respectively which indicated moderate reliability.

\subsubsection{Questionnaire for Students}

Aquestionnaire of 45 items was administered to students so as to find out their perceptions and practices of autonomous learning at Emdebir Preparatory School. Eight of the items in section two and seven items in section three of the questionnaire were adapted from Spratt, Humphreys and Chan (2002) and some items fromO' Malley and Chamot(1990) and Oxford (1990) were modified and used as a data collection instrument on language learning instrument.

Final draft of the questionnaire included two major parts. Part one contains students' personal information. Part two consists of four sections which include a total of 45 items. In section one, for practices of learner autonomy, students indicated their agreements or disagreements with the statements on five-point Likertscales ranging from 5 indicating "strongly agree", 4 indicating "agree",3 indicating "undecided", 2 indicating " disagree" and 1 indicating "strongly disagree". For responsibility perception section (item 16- 23) respondents were required to indicate their responses 
under three categories, 'teacher's responsibility', 'both teachers' and students' responsibility' and 'student's responsibility'. The ability section (item24-30) was arranged in a 5-point Likert scale (5- indicating "very good" 4 indicating "good", 3-indicating "uncertain", 2-"poor", 1-indicating "very poor"). For language learning strategy use (31-45), students indicated the frequency of strategy use - with the statements on five-point Likert scales ranging from 5 indicating "always" , 4 indicating "usually",3 indicating "sometimes" , 2 indicating " rarely" and 1 indicating "never"

\subsubsection{Questionnaire for teachers}

The teachers' questionnaire was designed in line with the students' questionnaire. A version of the same questionnaire was administered to the teachers of the sample group (see Appendix B). The items in section one were designed with the view to elicit information about the extent to which teachers use activities and tasks that support learner autonomy (item 1-15), section two was meant for teachers' perception of students' and their own responsibility(item16-23), section three for teachers perception of students' ability (item 24-30), section four for cognitive strategy (item 31- 36) and section five meta-cognitive strategy (items 37-45) are included.

\subsubsection{Interview with Students}

The purpose of the interview was to gather more information about students' ideas about learning English autonomously. A semi-structured interview was conducted with six students (See Appendix D, pp. 96). That means, out of 110 students, 6 students were taken (5.4 percent of the participants). The students who participated in the interview were selected using simple random sampling method. All the participants selected were willing to participate in the interview after the researcher discussed the objective of the study and assured them confidentiality. The interview, conducted in Amharic language, was recorded, and later transcribed and analyzed on the basis of the frequencies(See Appendix F). It took 45 minutes to complete conducting the interview. The result was used as a counter check of the data obtained from the students' questionnaire.

\subsubsection{Classroom Observation}

When observation is combined with other data collecting tools, it allows for an interpretation of the situation which is being studied. Four teachers out of eight were selected on voluntary basis. Four of the eight sections (B, C, F and $\mathrm{H})$ were selected randomly in which each of the teachers were observed twice. A check list was constructed by the researcher in order to specify the tasks and activities used within the classroom to promote autonomy of the learners. The checklist contained five points with two columns of 'Yes' or 'No' answers. At the end of the observation, the 'Yes' or 'No' categories were changed into five-point scales namely: Ineffective (0), less effective (1), fairly effective (2), effective (3), and very effective (4) The researcher objectively considered the learning opportunities created by teaching situations to promote learner autonomy in language learning. The co-observer and the researcher together saw the English lessons and put a tick mark on the checklist when they observed opportunities, strategies and procedures. Each session was scheduled for 45 minutes. The observation was conducted for eight periods all together; the four teachers were observed twice each. Totally, the classes were observed for six hours.

\subsection{Procedure for Data Collection.}

Prior to the implementation of the data collection, the permission of the principal was taken. Then, the selection of representative samples was carried out using lists of the students collected from home room teachers. Following arrangements suggested by the principals and participants, the final draft of the questionnaire was administered to 110 (69 males and 41 females) grade twelve students. The questionnaire was administered on-the-spot to avoid duplication of responses and to maximize return rate of questionnaire copies.

After gathering the students in a separate room, the researcher distributed the questionnaires and read through the cover page of the questionnaire to the students and explained the objective of the study before requesting them to answer the questions. Participants' confidentiality was guaranteed. The students completed the questionnaire in approximately 30 minutes time. The researcher told them to complete the questionnaires carefully and honestly. They were told that every student had to work on by himself/ herself without asking a friend. On the same day, the teachers were given the questionnaires and collected the following day.

Following arrangements of place and time in accordance with the convenience of student respondents, the interview was conducted in a classroom. The interview with students, Amharic, was conducted with each interviewee individually. One interview session was used with one student; the interactions were audio-recorded and played back during data analysis.

After the questionnaire and interview data were collected, classroom observation was conducted based on arrangements of place and time in accordance with the convenience of the informants.

\subsection{Method of Data Analysis}

Both quantitative and qualitative methods were applied in the analysis of the data.

\subsubsection{Quantitative Data Analysis}

The data obtained through questionnaire were analyzed using different kinds of statistical tools which were processed through Statistical Packages for Social Science (SPSS) window 15.0 software. Descriptivestatistical techniques of frequency, percentage and mean are used for data analysis. A 2x3 contingency table Chi-square is used to find out if there 
is a significant difference between students' and teachers' perception of responsibility in learning English. Besides, independent sample t-test is used to compute their perceptions of students'.

The total scores for activities, perception of responsibility and ability, and language learning strategies for the two groups of participants were computed. The mean and grand mean were employed to measure the central tendency of responses. The grand mean was calculated by adding all the means of the items divided by the number of items. For example, the grand mean for students' responses in section one is the mean values of students' responses on all of the fifteen items divided by fifteen. When grand mean value of the items in any of the variables was observed to be less than three, the researcher interpreted it as the respondents' tendency to "disagree". Grand mean values of three and greater than three were interpreted as "Undecided" and "Agree" in that order.

On the other hand, the researcher made an attempt to classify and summarize items that measure similar things together. For example, item number 31, 32 and 35 'elaboration strategy', 40 and 41 'monitoring strategies', 37,3839 and 45 'evaluation strategies' were analyzed together to make the discussion brief. On the other hand, for a negative statement on section one (item-8) the point values were reversed. Concerning this, (Gay and Airasian, 1988) states that the point values of Likert scales ( $S D=5, D=4, U=3, A=2, S A=1$ ) need to be reversed for negative statements, that is, $S A=1, A=2, U=3$, $\mathrm{D}=4, \mathrm{SD}=5$.

The Chi Square (a 2x3 contingency table Chi-square) was used to analyze if there was a significant difference between the perception of students and teachers regarding responsibility in learning English. According to Gay and Airasian (1988), the chi-square is appropriate when the data are in frequency counts or percentages occurring in different categories. It compares the proportions actually observed in a study to the proportions expected, to see if they are significantly different. In the case of this study, the categories are 'teachers' responsibility', 'both student's and teacher's responsibility' and 'student's responsibility'.

In order to analyze whether there was significant difference between the perception of students and teachers regarding students' ability in learning English, independent sample t-test was used. The t test for independent samples is used to determine whether there is probably a significant difference between the means of two independent samples (Gay and Airasian, 1988). The difference was taken to be significant at alpha 0.05 .

Regarding the classroom observation a checklist with five sets of points to be observed was prepared with categorical 'yes', 'no' columns. Each point had four sub-points under it. At the end of the observation, the 'Yes' or ' $\mathrm{No}^{\prime}$ categories were changed into five-point scales namely: Ineffective (0), less effective (1), fairly effective (2), effective (3), and very effective (4). In other words, if only 2 of the sub-points under one of the points were observed, then the point under observation was marked as 'fairly effective (2)'. Similarly, if 4 of the sub-points under any one of the points were observed, the point under observation was marked 'very effective (4), etc.

\subsubsection{Qualitative Data Analysis}

The data obtained through interview were grouped in to themes and coded. The interview data was analyzed based on the basis of frequencies. Besides, the responses were grouped and described thematically as supplementary evidence following the discussion of quantitative data.

\section{Findings and Discussion}

\subsection{Findings}

In order to achieve the objectives of the study and seek answers to the research questions raised in the first chapter of this thesis, necessary data were gathered using three methods: questionnaire, interview and classroom observation. The data collected were analyzed statistically using percentage, mean value, independent sample t-test, Chi-square and qualitative description. In the next sections, the data gathered through each method are treated separately and interpretations are made with the intention to reach possible conclusions that can lead to workable recommendations. In this study, three research questions were explained regarding grade twelve students' and teachers' perception and practice of learner autonomy in learning English. Two of the questionnaires were incomplete and they were discarded. Thus one-hundred and ten of the questionnaires were ready for analysis. The results are presented in the same order with the research questions produced for the study.

\subsubsection{Autonomous Learning Activities and Tasks}

The first research question was aimed at investigating whether grade twelve students and teachers practice autonomous learning activities and tasks in the instructional process. Section one of the students' and teachers' questionnaires consist of 15 items designed to examine whether students involve in autonomous learning activities in language learning process and teachers promote learner autonomy. The items on the teachers' questionnaire (See Appendix B, pp. 86) were analyzed in line with the students' questionnaire in all analysis sections of this study.

The items of this section were grouped into five categories to make the analysis manageable: Autonomous learning activities related with setting goals (item 1, 2, 3, 10 and11), self-evaluation (item 4, 5, 6, 7, 8, 9 and 12), cooperative learning activities (item 13, 14 and 15). Descriptive statistics was used to present the percentages, frequencies and means of the items. 


\begin{tabular}{|c|c|c|c|c|c|c|c|c|}
\hline S.n & $\begin{array}{c}\text { Items } \\
\end{array}$ & & SA(5) & $\mathbf{A ( 4 )}$ & UD(3) & DA(2) & SDA(1) & Mean \\
\hline \multirow[t]{2}{*}{1} & \multirow[t]{2}{*}{ I set goals by myself in learning English } & S & $19(17.2)$ & $17(15.4 \%)$ & $1(1 \%)$ & $46(42 \%)$ & $27(24.4 \%)$ & 2.5 \\
\hline & & $\mathrm{T}$ & $6(75 \%)$ & $2(25 \%)$ & - & - & - & 4.7 \\
\hline \multirow[t]{2}{*}{2} & \multirow[t]{2}{*}{$\begin{array}{l}\text { I set goals on improving my grade/ score I } \\
\text { previously earned in English }\end{array}$} & $\mathrm{S}$ & $31(28.3 \%)$ & $36(32.3 \%)$ & $2(2 \%)$ & $22(20 \%)$ & $19(17.4 \%)$ & 3.3 \\
\hline & & $\mathrm{T}$ & $5(62.5 \%)$ & $2(25 \%)$ & & $1(12.5 \%)$ & & 4.5 \\
\hline \multirow[t]{2}{*}{3} & \multirow{2}{*}{$\begin{array}{l}\text { I plan what activities to do in learning } \\
\text { English }\end{array}$} & $\mathrm{S}$ & $32(29.5 \%)$ & $43(39 \%)$ & $4(3.5 \%)$ & $13(12 \%)$ & $18(16 \%)$ & 2.5 \\
\hline & & $\mathrm{T}$ & & - & $1(12.5 \%)$ & $2(25 \%)$ & $5(62.5 \%)$ & 1.5 \\
\hline \multirow[t]{2}{*}{10} & \multirow[t]{2}{*}{$\begin{array}{l}\text { I set goals on the tasks and exercises I } \\
\text { should study by myself in learning English }\end{array}$} & $\mathrm{S}$ & $18(16.1 \%)$ & $25(22.7$ & $3(3 \%)$ & $35(31.8 \%)$ & $29(26.4 \%)$ & 2.8 \\
\hline & & $\mathrm{T}$ & $2(25 \%)$ & - & - & $2(25 \%)$ & $4(50 \%)$ & 2.0 \\
\hline \multirow[t]{4}{*}{11} & \multirow{2}{*}{$\begin{array}{l}\text { I plan how much vocabulary I need to } \\
\text { study a day }\end{array}$} & S & $17(15.5 \%)$ & $15(13.6 \%)$ & $6(5.4 \%)$ & $28(25.4 \%)$ & $34(30.9 \%)$ & 2.9 \\
\hline & & $\mathrm{T}$ & $2(25 \%)$ & $1(12.5 \%)$ & & $1(12.5 \%)$ & $4(50 \%)$ & 2.6 \\
\hline & \multirow{2}{*}{ Grand Mean } & $\mathrm{S}$ & \multicolumn{6}{|c|}{2.8} \\
\hline & & $\mathrm{T}$ & \multicolumn{6}{|c|}{2.9} \\
\hline
\end{tabular}

Table 1: Students' and Teachers' Responses on Setting Goals in Learning English Keys: SD=Strongly Disagree DA=Disagree UD (3) A=Agree SA=Strongly Agree, $\mathrm{T}=$ Teacher $\mathrm{S}=$ Students

Goal setting is an important component of autonomous learning. As can be seen from item 1 in the table above, the majority of the students reported their disagreement in setting goals for their own learning $(\mathrm{M}=2.5)$. However, almost all of the teachers reported their agreement about helping learners to set goals in learning English $(M=4.7)$.

Besides, on the second item the majority of the students reported that they set goals on improving their results/ grade $(\mathrm{M}=3.3)$. Similarly, the majority of the teachers indicated their agreement about guiding learners to plan what to do in learning English ( $M=4.5)$.

However, on the third item most of the students indicated their disagreement to plan activities to do in learning English $(\mathrm{M}=2.5)$. On the other hand, most of the teachers reported their disagreement about encouraging students to plan what activities to do by themselves ( $\mathrm{M}=1.5)$.

The tenth item was designed to find out whether students set goals about the tasks and exercises they need to study by themselves and whether teachers motivate learners to set these goals. In reacting to this item, the majority of students reported their disagreement about designing tasks and exercises by themselves $(\mathrm{M}=2.8)$. Concerning teachers' responses to this item, two-third of them showed their disagreement $(\mathrm{M}=2.0)$ to encourage learners set goals about tasks and exercises by themselves.

The other item with regards goal setting was planning the number of vocabularies students need to study (item 11). On this item, the majority of the students disclosed their disagreement about setting goals on their vocabulary study $(\mathrm{M}=2.9)$. Besides, more than two third of the teachers reported their disagreement in helping learners to practice this activity.

The grand mean of the student's responses on the entire goal setting activities $(M=2.8)$ confirms the finding that students lack setting goals in their learning. Students lack the readiness to involve in goal setting which is the basic aspect of autonomous learning. Although teachers reported that they encourage goal setting, the grand mean values of their responses $(\mathrm{M}=2.9)$ show their inadequate effort to help learners to set goals. The data show that teachers take on most of the responsibility in relation to this activity.

The other items in section one of the questionnaire are related with self-evaluation, which is an important basic activity in autonomous learning. The table below presents the frequency, percentage and mean values of students and teachers on this activity 


\begin{tabular}{|c|c|c|c|c|c|c|c|c|}
\hline S.n & Items & & SA(5) & $A(4)$ & UD(3) & DA(2) & SDA(1) & Mean \\
\hline \multirow[t]{2}{*}{4} & \multirow{2}{*}{$\begin{array}{l}\text { I note what I have learned } \\
\text { and achieved after each } \\
\text { reading lesson }\end{array}$} & S & $33(30 \%)$ & $16(14.6 \%)$ & $2(1.8 \%)$ & $35(32 \%)$ & $24(21.8 \%)$ & 2.9 \\
\hline & & $\mathrm{T}$ & - & $2(25 \%)$ & & $4(50 \%)$ & $2(25 \%)$ & 2.3 \\
\hline \multirow[t]{2}{*}{5} & \multirow{2}{*}{$\begin{array}{l}\text { I judge the effectiveness of } \\
\text { activities, topics and } \\
\text { materials I do in the English } \\
\text { classroom }\end{array}$} & $\mathrm{S}$ & $21(19.1 \%)$ & $20(18.2 \%)$ & $3(3 \%)$ & $30(27.3 \%)$ & $26(23.6 \%)$ & 2.5 \\
\hline & & $\mathrm{T}$ & $2(25 \%)$ & - & - & $2(25 \%)$ & $4(50 \%)$ & 2.2 \\
\hline \multirow[t]{2}{*}{6} & \multirow{2}{*}{$\begin{array}{l}\text { I figure out solutions to } \\
\text { problems in learning English } \\
\text { by myself }\end{array}$} & $\mathrm{S}$ & $18(16.1 \%)$ & $25(22.7 \%)$ & $3(3 \%)$ & $35(31.8 \%)$ & $29(26.4 \%)$ & 2.8 \\
\hline & & $\mathrm{T}$ & - & $2(25 \%)$ & - & $2(25 \%)$ & $4(50 \%)$ & 2.0 \\
\hline \multirow[t]{2}{*}{7} & \multirow{2}{*}{$\begin{array}{l}\text { I wait until the teacher helps } \\
\text { me in seeking out solutions } \\
\text { for learning problems }\end{array}$} & $\mathrm{S}$ & $44(40 \%)$ & $27(24.5 \%)$ & $2(1.8 \%)$ & $20(18.2 \%)$ & $17(15.5 \%)$ & 3.6 \\
\hline & & $\mathrm{T}$ & - & - & $1(12.5 \%)$ & $5(62.5 \%)$ & $2(25 \%)$ & 1.5 \\
\hline \multirow[t]{2}{*}{8} & \multirow{2}{*}{$\begin{array}{c}\text { I do not evaluate my } \\
\text { language learning progress } \\
\text { by my myself }\end{array}$} & $\mathrm{S}$ & $43(39.1 \%)$ & $36(32.7 \%)$ & $2(1.8 \%)$ & $12(11 \%)$ & $15(13.6 \%)$ & 2.2 \\
\hline & & $\mathrm{T}$ & $1(12.5 \%)$ & $1(12.5 \%)$ & - & $4(50 \%)$ & $2(25 \%)$ & 2.4 \\
\hline \multirow[t]{2}{*}{9} & \multirow{2}{*}{$\begin{array}{l}\text { I discuss my language } \\
\text { learning progress with } \\
\text { friends }\end{array}$} & S & $12(11.9 \%)$ & $18(16.1 \%)$ & - & $34(31 \%)$ & $43(39.1 \%)$ & 3.1 \\
\hline & & $\mathrm{T}$ & & & $1(12.5 \%)$ & $5(62.5 \%)$ & $2(25 \%)$ & 1.9 \\
\hline \multirow[t]{4}{*}{12} & \multirow{2}{*}{$\begin{array}{c}\text { I think about how I can learn } \\
\text { better to suit my learning } \\
\text { styles }\end{array}$} & $\mathrm{S}$ & $18(16 \%)$ & $20(18 \%)$ & $5(4.5 \%)$ & $32(29 \%)$ & $35(32.5 \%)$ & 2.6 \\
\hline & & $\mathrm{T}$ & $2(25 \%)$ & & $2(25 \%)$ & $3(37.5)$ & $1(12.5 \%)$ & 2.5 \\
\hline & \multirow[t]{2}{*}{ Grand Mean } & $\mathrm{S}$ & \multicolumn{6}{|c|}{2.4} \\
\hline & & $\mathrm{T}$ & \multicolumn{6}{|c|}{2.2} \\
\hline
\end{tabular}

Table 2: Students' and Teachers' Responses on Evaluation Activities in Language Learning

Keys: SD=Strongly Disagree DA=Disagree UD (3) A=Agree SA=Strongly Agree,

$\mathrm{T}=$ Teachers $=$ Students

On item 4 which aims to find out whether students evaluate their progress after reading lessons the majority of them showed their disagreement( $M=2.9)$. Similarly, three- fourth of the teachers reported their disagreement about encouraging learners to evaluate their progress after reading lessons $(\mathrm{M}=2.3)$.

On the other hand, the majority of the students $(M=2.8)$ showed their disagreement about figuring out solutions to their language learning problems by themselves (Item 6). This suggests that they tend to depend on their teachers in solving learning problems. In addition, more than two-third of the students reported that they their teachershelp in seeking out solutions to their problems in learning English (Item 7). On the other hand, three fourth of the teachers showed their disagreement in letting students to look for solutions to problems in learning English by themselves ( $\mathrm{M}=2.0)$. In other words, the data show that teachers had the tendency to solve students' learning problems instead of encouraging learners to do this by themselves. Autonomous learners attempt to seek ways of solving their learning problems by themselves which the participants of this study lack.

The eighth and ninth items were intended to find out whether students evaluate their learning progress and whether teachers encourage learners' self-evaluation. For example, in reacting to the eighth item, $71.8 \%$, (39.1\% 'strongly agreeing' and $32.7 \%$ 'agreeing'), of the students reported that they do not evaluate their learning progress. Besides, the responses to item 9 displays that $70 \%$ of the students reported their disagreement concerning talking about their progress. However, two-third of the teachers reported their disagreement on helping learners to evaluate their language learning progress. In addition, $87.5 \%$ of the teachers showed their disagreement about encouraging students to talk about their learning progress (item 9). Therefore, the data show that students and teachers do not seem to promote evaluation of learning progress. Their practice in relation to this activity does not seem to be autonomy supportive.

The twelfth item intends to find out whether they evaluate the learning process in relation to suit their learning styles and preferences, and whether teachers respond to students' learning styles in learning English $(\mathrm{M}=2.9)$. On the other hand, the majority of the teachers reported their disagreement about providing learners with opportunities that suit different learning styles $(M=2.5)$. From the data we can see that students lack to find out whether the learning situation satisfies their styles and preferences and that teachers lack promoting learner styles and preferences.

The findings of this section reveal that students lack to exert their effort to involve in evaluative activities like evaluating learning progresses, evaluate task effectiveness, and identify solutions to learning problems and assess ways that suit their learning styles. The grand mean of their responses on all of these items $(\mathrm{M}=2.2)$ confirms this finding. Similarly, the grand mean of teachers' responses on these items $(M=2.4)$ does not seem to support learners' selfevaluation. 


\begin{tabular}{|c|c|c|c|c|c|c|c|c|}
\hline S. $\mathbf{N}$. & Items & & SA(5) & $\mathrm{A}(4)$ & UD(3) & DA(2) & SDA(1) & Mean \\
\hline \multirow[t]{2}{*}{13} & \multirow{2}{*}{$\begin{array}{l}\text { I organize my own learning in } \\
\text { group works by myself }\end{array}$} & $\mathrm{S}$ & $25(22 \%)$ & $22(19 \%)$ & & $29(27 \%)$ & $34(32 \%)$ & 2.7 \\
\hline & & $\mathrm{T}$ & $4(50 \%)$ & $2(25 \%)$ & - & $2(25 \%)$ & & 4.0 \\
\hline \multirow[t]{2}{*}{14} & \multirow{2}{*}{$\begin{array}{l}\text { I work cooperatively with other } \\
\text { students }\end{array}$} & $\mathrm{S}$ & $23(21 \%)$ & $11(10 \%)$ & $1(1 \%)$ & $35(32 \%)$ & $40(36.4 \%)$ & 2.7 \\
\hline & & $\mathrm{T}$ & $5(62.5 \%)$ & $3(375 \%)$ & & & & 46 \\
\hline \multirow[t]{2}{*}{15} & \multirow{2}{*}{$\begin{array}{l}\text { I involve in autonomous learning } \\
\text { activities like project work }\end{array}$} & $\mathrm{S}$ & $18(16 \%)$ & $11(10 \%)$ & $3(3 \%)$ & $33(30 \%)$ & $45(41 \%)$ & 2.3 \\
\hline & & $\mathrm{T}$ & $2(25 \%)$ & $6(75 \%)$ & & & & 4.3 \\
\hline & \multirow[t]{2}{*}{ Grand mean } & $\mathrm{S}$ & \multicolumn{6}{|c|}{2.5} \\
\hline & & $\mathrm{T}$ & \multicolumn{6}{|c|}{4.3} \\
\hline
\end{tabular}

Table 3: Students' and Teachers' Responses on Cooperative Learning Activities

Keys: SD=Strongly Disagree DA=Disagree UD (3) A=Agree SA=Strongly Agree, $\mathrm{T}=$ Teacher S=Students

Cooperative learning activities like group and pair works are learning conditions in which learners practice taking control of their learning. Using such activities learners can have the opportunity to plan, coordinate and evaluate their learning. On the thirteenth item, more than half $59 \%$ of the students indicated their disagreement (both 'strongly disagree' and 'disagree') that they organize their own learning by themselves where as $41 \%$ of them agreed on this item. Similarly, $75 \%$ of the teachers indicated their agreement, that they encourage students to organize their own learning by themselves. Organizing one's learning requires managing effort and time in learning. The majority of the students reported that they organize their own learning.

Moreover, on the fourteenth item students disclosed that they work cooperatively with other students and that teachers involve learners in cooperative learning. For this item, a significant number of student respondents indicated their disagreement (32\% 'strongly disagreeing' and 36.4\% 'disagreeing') to work cooperatively with other students. The data show that students lack the need for relatedness. Concerning teachers' responses to this item, three-fourth of them disclosed their agreement (both 62.5\% 'strongly agreeing' and 37.5 'agreeing') that they motivate learners to work cooperatively with other students.

The last item was aimed to ferret out whether students involve in autonomous learning activities like project work. As it can be seen from the data, $71 \%$ of the students disclosed their disagreement about involving in such activities whereas only $26 \%$ of them indicated their agreement. However, all of the teachers showed their agreement that they motivate students to involve in project works. The findings of items 13 through 15 are consistent with each other both for student (Grand mean=2.5) and teacher respondents (Grand mean=4.3) in which students reported their disagreement that they work with others and organize their learning. However, the findings indicated that teachers encouraged learners to work cooperatively and organize their learning. This finding is inconsistent with the teachers' responses to item 3 above in which the teachers' practice was found to be unsystematic and unplanned to help learners take responsibility in group works.

On the other hand, the aggregate percentage values of all the 15 items show that $22.5 \%$ and $20.6 \%$ of the students indicated their strong agreement and agreement respectively concerning their involvement in autonomous learning activities. Similarly, $28.1 \%$ and $26 \%$ of them strongly disagree and disagree respectively about involving in autonomous learning activities and tasks. On the other hand, $25.8 \%$ and $17.5 \%$ of them reported their strong agreement and agreement respectively where as $26.6 \%$ and $27.5 \%$ of the teachers indicated their strong disagreement and disagreement about encouraging learners involve in autonomous learning activities.

\begin{tabular}{|c|c|c|c|c|}
\hline & Goal setting & Self-evaluation & $\begin{array}{c}\text { Cooperative } \\
\text { learning }\end{array}$ & Grand Mean \\
\hline $\mathrm{S}$ & 2.8 & 2.6 & 2.5 & 2.4 \\
$\mathrm{~T}$ & 2.9 & 2.5 & 4.3 & 2.8 \\
\hline
\end{tabular}

Table 4: Grand Mean Distribution of Students' and

Teachers' Responses on All Of the

Autonomous learning activities

Keys: $\mathrm{T}=$ Teacher $\mathrm{S}=$ Students

To sum up, the grand mean for students $(\mathrm{M}=2.4)$ in all of the autonomous learning activities indicate that they do not seem to exert effort to learn English by themselves. They do not seem to involve in autonomous activities and tasks such as setting goals for their learning, figuring out solutions to problems and evaluating learning progress and involve in cooperative learning activities. Similarly, the grand mean for teachers $(M=2.8)$ indicate that they do not seem to help learners in setting goals, encourage them to evaluate their language learning performance by themselves. However, the majority of the teachers reported that they encourage learners to set learning goals and involve learners in cooperative activities. 


\subsubsection{Students' and Teachers' Perceptions of Learner Autonomy in Learning English}

The second research question was about student' and teachers' perception of learner autonomy in learning

English. This question was aimed at investigating the participants' perceptions of responsibility and ability in learning

English and whether there was significant difference between their perceptions with regards learner autonomy.

\subsubsection{Students' and Teachers' Perceptions of Responsibility in Language Learning}

The data concerning responsibility were gathered by section two of the questionnaire (See AppendixA). With the help of descriptive statistics, the percentage and frequencies of the items are presented.

\begin{tabular}{|c|c|c|c|c|c|c|}
\hline No & \multicolumn{2}{|l|}{$\begin{array}{c}\text { Item } \\
\text { In teaching and learning English, } \\
\text { whose responsibility should it be? }\end{array}$} & $\begin{array}{c}\text { Teachers } \\
\text { responsibility }\end{array}$ & $\begin{array}{l}\text { Both teachers and } \\
\text { student's } \\
\text { responsibility }\end{array}$ & $\begin{array}{c}\text { Students } \\
\text { responsibility }\end{array}$ & $\begin{array}{c}\text { Chi-square } \\
\left(\mathbf{x}^{2}\right)\end{array}$ \\
\hline \multirow[t]{2}{*}{16} & \multirow{2}{*}{$\begin{array}{l}\text { Deciding the objectives of the } \\
\text { English lesson }\end{array}$} & $\mathrm{S}$ & $47(43 \%)$ & $43(39 \%)$ & $20(18 \%)$ & \multirow[b]{2}{*}{2.75} \\
\hline & & $\mathrm{T}$ & $7(75 \%)$ & $1(25 \%)$ & & \\
\hline \multirow[t]{2}{*}{17} & \multirow{2}{*}{$\begin{array}{l}\text { Deciding what will be learnt in } \\
\text { the next English class }\end{array}$} & $\mathrm{S}$ & $53(48.2 \%)$ & $38(34.5 \%)$ & $19(17.3 \%)$ & \multirow[b]{2}{*}{2.65} \\
\hline & & $\mathrm{T}$ & $5(62.5 \%)$ & $2(25 \%)$ & $1(12.5 \%)$ & \\
\hline \multirow[t]{2}{*}{18} & \multirow{2}{*}{$\begin{array}{c}\text { Deciding how long to spend on } \\
\text { each activity }\end{array}$} & $\mathrm{S}$ & $61(55.4 \%)$ & $30(27.3 \%)$ & 19(17.3\%) & \multirow[b]{2}{*}{2.35} \\
\hline & & $\mathrm{T}$ & $5(62.5 \%)$ & $2(25 \%)$ & $1(12.5 \%)$ & \\
\hline \multirow[t]{2}{*}{19} & \multirow{2}{*}{$\begin{array}{c}\text { Choosing what } \\
\text { materials/ activities to use in the } \\
\text { English class } \\
\end{array}$} & $\mathrm{S}$ & $58(53 \%)$ & $40(36 \%)$ & $12(11 \%)$ & \multirow[b]{2}{*}{2.65} \\
\hline & & $\mathrm{T}$ & $7(87.5 \%)$ & $1(12.5 \%)$ & & \\
\hline \multirow[t]{2}{*}{20} & \multirow{2}{*}{$\begin{array}{l}\text { Identifying students' weaknesses } \\
\text { and strengths in learning English }\end{array}$} & $\mathrm{S}$ & $65(59.1 \%)$ & $28(25.4 \%)$ & $17(15.4 \%)$ & \multirow[t]{2}{*}{5.79} \\
\hline & & $\mathrm{T}$ & $4(50 \%)$ & $3(37.5 \%)$ & $1(12.5 \%)$ & \\
\hline \multirow[t]{2}{*}{21} & \multirow{2}{*}{$\begin{array}{l}\text { Making sure students make } \\
\text { progress during English lesson }\end{array}$} & S & $63(57.3 \%)$ & $33(30 \%)$ & $14(12.7 \%)$ & \multirow[t]{2}{*}{2.56} \\
\hline & & $\mathrm{T}$ & $3(37.5 \%)$ & $4(50 \%)$ & $1(12.5 \%)$ & \\
\hline \multirow[t]{2}{*}{22} & \multirow[t]{2}{*}{ Evaluating learning performance } & $\mathrm{S}$ & $72(65.5 \%)$ & $27(24.5 \%)$ & $10(9 \%)$ & \multirow[b]{2}{*}{2.13} \\
\hline & & $\mathrm{T}$ & $6(75 \%)$ & $1(12.5 \%)$ & $1(12.5 \%)$ & \\
\hline \multirow[t]{2}{*}{23} & \multirow{2}{*}{$\begin{array}{c}\text { Correcting students' mistakes in } \\
\text { learning English }\end{array}$} & $\mathrm{S}$ & $30(27 \%)$ & $68(62 \%)$ & $12(11 \%)$ & \multirow[b]{2}{*}{2.04} \\
\hline & & $\mathrm{T}$ & $1(12.5 \%)$ & $5(62.5 \%)$ & $2(25 \%)$ & \\
\hline & \multirow[t]{2}{*}{ Cumulative average frequencies } & $\mathrm{S}$ & $56.2(51.1 \%)$ & $38.4(34.9 \%)$ & $15.4(14 \%)$ & \multirow{3}{*}{286} \\
\hline & & $\mathrm{T}$ & $4.7(59.4 \%)$ & $2.4(30 \%)$ & $0.9(10 \%)$ & \\
\hline & Average Chi-square value & & & & & \\
\hline
\end{tabular}

Table 5: Students' and Teachers' Responses on Responsibility Perceptions

Where the Observed Chi-Square Value (X) Is Less Than the Table (Critical) Value for Chi-Square (X2, 5.99, with Df=(R-1) (C-1) $=2$ and Alpha $=0.05$,Was Taken as Not Significant Difference Between the Responses of Students and Teachers Concerning

Responsibility Perception

Table 5 reveals the percentages, frequencies and the Chi-square values of students' and teachers' responses to their perceptions of each other's responsibilities. A $2 \times 3$ contingency table regarding responsibility was conducted to evaluate any significant differences between the perceptions of teachers and students.

The data on table 5show that the majority of students and teachers gave more responsibility to teachers than students. On the sixteenth item, $43 \%$ of students and $75 \%$ of the teachers gave more responsibility to the teacher concerning the decision to be taken on objectives of the English lesson $\left(\mathrm{x}^{2}=2.75\right)$. Similarly, $48.2 \%$ of the students and $62.5 \%$ of the teachers considered decision making about the content of English lessons as teachers' responsibility $\left(\mathrm{x}^{2}=2.65\right)$. Furthermore, concerning the decision about the time limit to be spent on each activity (item 18), $55.4 \%$ of the students and $62.5 \%$ of the teachers thought this as teacher's responsibility, $\left(\mathrm{x}^{2}=2.35\right)$. Moreover, on item 19both students and teachers shared similar belief regarding materials and activities to be used in the English class $\left(\mathrm{x}^{2}=2.65\right)$. In this item, too, both groups of respondents gave more responsibility to the teachers than students. The data from both groups of respondents on items 16,17, 18 and 19 indicate that approximately $76 \%$ of the students and $84 \%$ of the teachers on the average considered teachers as more responsible for decisions relating to formal language instruction.

Similarly, on item 20 the majority of students (59.1\%) and teachers (50\%) believed that teachers were more responsible for identifying students' weaknesses and strengths in learning English with $\left(\mathrm{x}^{2}=5.79\right)$.

On item 21 , while the majority of the students $(57.3 \%)$ thought that teachers were more responsible for making sure students make progress during English lesson $\left(\mathrm{x}^{2}=2.56\right), 50 \%$ of the teachers believed that both students and teachers were responsible in this regard.

Furthermore, on item 22, both students and teachers showed similar perception of responsibly, $65.5 \%$ of the students and $75 \%$ of the teachers gave more responsibility to the teacher than the students for evaluating learning performance $\left(x^{2}=2.13\right)$. While only $9 \%$ of the students considered students more responsible in evaluating learning performance $12.5 \%$ of the teachers considered this as students' responsibility. 
However, only on item 23 , both students and teachers had the notion of shared responsibility, $68 \%$ of the students and $62.5 \%$ of the teachers considered correcting students' mistakes in learning English as both students, and teachers' responsibility $\left(\mathrm{x}^{2}=2.04\right)$.

On the other hand, the cumulative average frequencies of both students and teachers concerning responsibility perception (See table-5) depicts that the majority of both students and teachers gave more responsibility to teachers. Out of 110 students, 56.2 of them gave responsibility to the teacher, 38.4 of them were ready to share responsibility with the teacher and only 15.4 of them on the average considered themselves more responsible in the process of language learning. Similarly, while 4.75 of them considered themselves responsible, 2.4 of them were ready to share responsibility with their students. But only 0.9 of them on the average gave more responsibility to students than themselves in language learning.

To sum up, the observed Chi-square value (the average of Chi-square value for all of the responsibility perception items $(2.75+2.35+2.65+5.79+2.56+2.13+2.04$ divided by seven=2.86) is not greater than the table value, 5.99 . This shows that there was no significant difference between students' and teachers' perceptions of responsibility. In other words, there is a match between perceptions of the two groups concerning responsibility in learning English. That means, both students and teachers considered that teachers were more responsible than students in deciding what will be learnt in the next English class, how long to spend on each activity, choosing what materials/ activities to use in the English class, identifying students' weaknesses and strengths in learning English, making sure students make progress during English lesson and evaluating learning performance which were related to formal language instruction. However, only in one of the eight items both students and teachers had the notion of shared responsibility to correct students' mistakes in learning English.

\subsubsection{Students' and Teachers' Perceptions of Abilities in Language Learning}

In the third section of the students' and teachers' questionnaire (See Appendix A and B) both groups of participants in the study were asked how they thought about students' abilities to behave autonomously. With the help of descriptive statistics, the percentage and frequencies of the items are presented. An independent sample t-test was used to see whether there was significant difference between students' and teachers' perceptions of students' ability in learning English.

\begin{tabular}{|c|c|c|c|c|c|c|c|c|}
\hline No & \multicolumn{2}{|l|}{ Items } & 5 & 4 & 3 & 2 & 1 & Mean \\
\hline \multirow[t]{2}{*}{24} & \multirow[t]{2}{*}{ Carry out learning goals } & $\mathrm{S}$ & $42(38.2 \%)$ & $38(34.5 \%)$ & $7(6.4 \%)$ & $14(12.7 \%)$ & $9(8.2 \%)$ & 3.8 \\
\hline & & $\mathrm{T}$ & & $1(12.5 \%)$ & $2(25 \%)$ & $4(50 \%)$ & $1(12.5 \%)$ & 2.4 \\
\hline \multirow[t]{2}{*}{25} & \multirow[t]{2}{*}{ Plan works in learning English } & $\mathrm{S}$ & $30(27.3 \%)$ & $47(42.7 \%)$ & $5(4.5 \%)$ & $12(11 \%)$ & $16(14.5 \%)$ & 3.5 \\
\hline & & $\mathrm{T}$ & & $2(25 \%)$ & $2(25 \%)$ & $4(50 \%)$ & & 2.7 \\
\hline \multirow[t]{2}{*}{26} & \multirow[t]{2}{*}{$\begin{array}{l}\text { Learn successfully without teacher } \\
\text { supervision }\end{array}$} & $\mathrm{S}$ & $12(10.9 \%)$ & $18(16.4 \%)$ & $7(6.4 \%)$ & $40(36.6 \%)$ & $33(30 \%)$ & 2.5 \\
\hline & & $\mathrm{T}$ & & & $2(25 \%)$ & $4(50 \%)$ & $2(25 \%)$ & 2.0 \\
\hline \multirow[t]{2}{*}{27} & \multirow[t]{2}{*}{ Make choices about what work to do } & $\mathrm{S}$ & $31(28.2 \%)$ & $38(34.5 \%)$ & $8(7.3 \%)$ & $12(11 \%)$ & $20(18.2 \%)$ & 3.3 \\
\hline & & $\mathrm{T}$ & & & $3(37.5 \%)$ & $2(25 \%)$ & $3(37.5 \%)$ & 2.0 \\
\hline \multirow[t]{2}{*}{28} & \multirow[t]{2}{*}{$\begin{array}{l}\text { Choose the exercises and tasks to work } \\
\text { on }\end{array}$} & $\mathrm{S}$ & $26(23.6 \%)$ & $43(39.1 \%)$ & $2(1.8 \%)$ & $20(18.2 \%)$ & $19(17.3 \%)$ & 3.3 \\
\hline & & $\mathrm{T}$ & & & $2(25 \%)$ & $2(25 \%)$ & $4(50 \%)$ & 2.6 \\
\hline \multirow[t]{2}{*}{29} & \multirow[t]{2}{*}{ Evaluate learning abilities } & $\mathrm{S}$ & $22(20 \%)$ & $29(26.6 \%)$ & $21(19.1 \%)$ & $17(15.5 \%)$ & $21(19.1 \%)$ & 3.1 \\
\hline & & $\mathrm{T}$ & $2(25 \%)$ & & $2(25 \%)$ & $2(25 \%)$ & $2(25 \%)$ & 2.7 \\
\hline \multirow[t]{3}{*}{30} & \multirow[t]{2}{*}{$\begin{array}{l}\text { Test yourself to see how much you have } \\
\text { learned }\end{array}$} & $\mathrm{S}$ & $35(31.8 \%)$ & $45(41 \%)$ & $4(3.6 \%)$ & $20(18.2 \%)$ & $16(14.5 \%)$ & 3.6 \\
\hline & & $\mathrm{T}$ & $2(25 \%)$ & & & $4(50 \%)$ & $2(25 \%)$ & 2.5 \\
\hline & Grand mean & $\frac{S}{T}$ & & & & & & $\frac{3.3}{24}$ \\
\hline
\end{tabular}

Table 6: Student' and Teachers' Responses on Perceptions of Ability in Learning English

Keys-Very Good-5, Good-4, Uncertain-3, Poor-2, Very Poor-1T=Teachers, S=Students 
In the table above, while the highest percentage of students' responses for each of section three item is in "Very Good"/ "Good" columns, the majority of teachers' responses are in either "poor" or" very poor" columns (See items 25, 24, 27, 28 and 30). In these items' students showed positive perception about their ability where as teachers did the reverse.

However, only on item 26 , which asked whether students had the ability to learn successfully without teacher supervision both groups of respondents held similar belief, $36.6 \%$ and $30 \%$ of the students reported "poor" and "very poor "respectively. Similarly, $50 \%$ and $25 \%$ of teachers indicated "poor" and "very poor" respectively concerning their perception of student's ability to learn successfully without teacher supervision. Only $6.4 \%$ of them reported that they were uncertain about their ability. Even though students evaluated their ability positively, they showed a need to depend on their teacher's help. The data on item 26 suggest that the students were taught in traditional language learning environment where the teacher was seen as a dominant figure in the language learning process.

Moreover, if we see the mean values of students' responses on allof the sevenitems except the twenty sixthitem whose mean value $(M=2.5)$ is more than the average mean $(M=3.0)$, show students' positive views about their ability. However, the mean values of the teachers' responses to each of the itemson table 5 is less than the average value( $M=3.0)$.

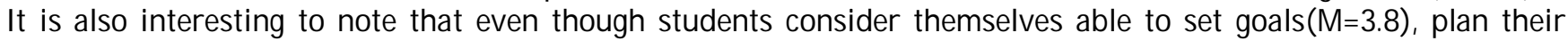
learning( $\mathrm{M}=3.5)$, decide on what work to do $(\mathrm{M}=3.3)$ and evaluate their learning performance $(\mathrm{M}=3.1)$, they prefer to pass responsibility to the teacher. While students believed that they were able to learn by themselves (grand mean of their ability perception is 3.3), they gave more responsibility to their teacher than themselves (see the discussion made under responsibility section).

To sum up, students' grand mean value on all of ability perception items 3.3 reveal that they evaluate their abilities positively whereas teachers' grand mean on these items, 2.3 , which is less than the average value indicate that they consider students' abilities in learning English as 'poor'. This shows mismatch between perceptions of students and teachers about students' ability in learning English.

So far, we have seen that there was response difference between students' and teachers' perception of abilities in language learning. However, is this difference significant? Table-7shows whether or not the difference is significant. The independent sample t-test answers this question.

\begin{tabular}{|c|c|c|c|c|c|c|}
\hline & $\mathbf{N}$ & Mean & Std. Deviation & Std. Error Mean & $\mathbf{t}$ & \multirow{3}{*}{$\begin{array}{c}\text { Sig. } \\
\text { (2-tailed) } \\
0.00\end{array}$} \\
\hline S & 110 & 3.3 & 5.47 & .522 & \multirow{2}{*}{$3.34 *$. } & \\
\hline $\mathrm{T}$ & 8 & 2.3 & 3.66 & 1.45 & & \\
\hline
\end{tabular}

While students (Grand mean=3.3) evaluate themselves positively, teachers (Grand mean $=2.3$ ) seem to evaluate students incompetent to learn independently. The results of the independent sample t-test indicated that there is a significant difference between the teachers' and students' responses in terms of perception of abilities in language learning $(t=3.34, \mathrm{P}<0.05)$. This significant difference shows that there is a mismatch between students and teachers concerning their perception of ability.

\subsubsection{Language Learning Strategies Employed by Students and Teachers in Teaching Learning English}

In the third research question, the aim was to find out the extent of language learning strategies grade 12 students and teacher's employ. The findings of this question are presented here below.

\subsubsection{The Cognitive Strategies Employed by Students and Teachers in Teaching Learning English}

The data regarding cognitive strategies were gathered by section 4 of the students' and teachers' questionnaire which contained six items on a five-point Liker scale. Descriptive statistics was used to portray the percentage, frequencies and means of the responses. 


\begin{tabular}{|c|c|c|c|c|c|c|c|c|}
\hline S. $n$ & \multicolumn{2}{|l|}{ Item } & 5 & 4 & 3 & 2 & 1 & Mean \\
\hline \multirow[t]{2}{*}{31} & \multirow{2}{*}{$\begin{array}{l}\text { I judge my ability after I read } \\
\text { books (academic or general)- }\end{array}$} & $\mathrm{S}$ & $49(44.5 \%)$ & $27(24.5 \%)$ & $7(6.4 \%)$ & $10(9.1 \%)$ & $7(6.3 \%)$ & 3.7 \\
\hline & & $\mathrm{T}$ & - & $6(75 \%)$ & - & $2(25 \%)$ & - & 3.5 \\
\hline \multirow[t]{2}{*}{32} & \multirow{2}{*}{$\begin{array}{l}\text { I judge the quality of materials } \\
\text { while I am reading- }\end{array}$} & $\mathrm{S}$ & $47(42.7 \%)$ & $26(23.6 \%)$ & $9(2.7 \%)$ & $9(8.1 \%)$ & $11(10 \%)$ & 3.5 \\
\hline & & $\mathrm{T}$ & $2(25 \%)$ & $2(25 \%)$ & $1(12.5 \%)$ & $3(35.5 \%)$ & & 3.3 \\
\hline \multirow[t]{2}{*}{33} & \multirow{2}{*}{$\begin{array}{l}\text { I use English language reference } \\
\text { books (dictionaries, encyclopedia, } \\
\text { journals, etc.) }\end{array}$} & $\mathrm{S}$ & $33(30 \%)$ & $37(33.6 \%)$ & $10(9.1 \%)$ & $21(19.9 \%)$ & $9(8.1 \%)$ & 3.6 \\
\hline & & $\mathrm{T}$ & $2(25 \%)$ & $4(50 \%)$ & $2(25 \%)$ & & & 4.5 \\
\hline \multirow[t]{2}{*}{34} & \multirow{2}{*}{$\begin{array}{l}\text { I take the responsibility to outline } \\
\text { a summary of reading text }\end{array}$} & $\mathrm{S}$ & $34(30.1 \%)$ & $26(23.6 \%)$ & $11(10 \%)$ & $18(16.3 \%)$ & $11(10 \%)$ & 3.2 \\
\hline & & $\mathrm{T}$ & - & $4(50 \%)$ & $2(25 \%)$ & $2(25 \%)$ & & 3.3 \\
\hline \multirow[t]{2}{*}{35} & \multirow{2}{*}{$\begin{array}{l}\text { I relate the skills I learned in } \\
\text { reading lessons in dealing with } \\
\text { extensive / intensive reading }\end{array}$} & $\mathrm{S}$ & $45(40.9 \%)$ & $37(33.6 \%)$ & $9(9 \%)$ & $9(9 \%)$ & $4(3.6 \%)$ & 3.9 \\
\hline & & $\mathrm{T}$ & $2(25 \%)$ & $4(50 \%)$ & $1(12.5 \%)$ & $1(12.5 \%)$ & & 3.9 \\
\hline \multirow[t]{4}{*}{36} & \multirow{2}{*}{$\begin{array}{l}\text { I take charge of taking the main } \\
\text { idea/ points from lecture/ books }\end{array}$} & $\mathrm{S}$ & $37(33.6)$ & $35(31.8 \%)$ & - & $13(11.8 \%)$ & $7(6.3 \%)$ & 3.3 \\
\hline & & $\mathrm{T}$ & $2(25 \%)$ & $6(75 \%)$ & - & - & - & 4.3 \\
\hline & \multirow[t]{2}{*}{ Grand mean } & $\mathrm{S}$ & & & & & & 3.5 \\
\hline & & $\mathrm{T}$ & & & & & & 3.8 \\
\hline
\end{tabular}

Table 8: Students' and Teachers' Responses on the Use of Cognitive Strategies in Teaching-

Learning English

Keys-Always-5, Usually-4, Sometimes-3, Rarely-2, Never-1T=Teacher, S=Student

Table- 8 illustrates the percentages and frequencies of students' and teachers' responses in employing cognitive strategies in learning and teaching English respectively at the stated grade level.

As can be seen from the data, the majority, $44.5 \%$ always and $24.5 \%$ usually, of the students reported that they judge their ability. On the other hand, $75 \%$ of the teachers reported that they usually encourage learners to judge their ability after reading books. The data indicated that the students seemed to judge their ability after reading materials and teachers tried to promote this strategy,

Furthermore, the data on item 32 show that the majority (42.7\% always and $23.6 \%$ usually) of the students reported that they judge the quality of materials while they read, where as only $18.1 \%$ (for both rarely and never) of them do this. The number of students who reported frequent use of elaboration strategy on this item exceeds those who rarely and never use by $48 \%$.The responses of both students and teachers to the above two items show that they use elaboration strategy in the language learning process.

On item 33, the majority (66.6\%) of the students, $30 \%$ always and 33.6\% usually, reported that they use English language learning reference books. Only $9.1 \%$ of them reported that they sometimes use this strategy. Similarly, $75 \%$ ( $25 \%$ always and $50 \%$ usually) of the teachers encourage students to use reference books in learning English. The data indicate that teachers provide appropriate information on how to use materials in learning English.

Item 34 was about students' use of summary writing skills in learning English and whether teachers encourage learners to use this skill. On this item, $64 \%$ of the students indicated that they always and usually make a summary of a reading text where as $50 \%$ of the teachers reported that they usually help learners to write a summary of reading text by them.

Concerning students' use of elaboration strategy in learning English, most (74.5\%) of the students, $40.9 \%$ always and $33.6 \%$ usually, reported that they relate the skills they learned in reading lessons in dealing with extensive reading lessons (item-35). Concerning the teachers' responses, three-fourth of the teachers (75\%), 25\% always and 50\% usually, encourage students to relate the skills they learn in reading lessons in dealing with extensive reading.

On item 36, the majority $65.4 \%, 33.6 \%$ always and $31.8 \%$ usually, of the students indicated that they take note in learning English. On the other hand, $13.6 \%$ of them rarely and never do this. With regards teachers' responses, $25 \%$ and $75 \%$ of them reported that they always and usually encourage students to take notes by themselves respectively.

The mean values of the items show that the most frequently employed cognitive strategies by students were elaboration

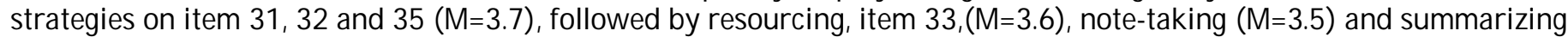
$(\mathrm{M}=3.2)$. On the other hand, teachers employ resourcing $(\mathrm{M}=4.5)$ strategy most frequently followed by note-taking $(\mathrm{M}=4.3)$, elaboration( $\mathrm{M}=3.5)$ and summarizing $(\mathrm{M}=3.3)$.

Generally, the data on this section indicate that students and teachers employ cognitive strategy in the learning process. The grand mean values of, on all of the cognitive strategy items, students $(M=3.5)$ and teachers ( $M=3.8)$ usually employ cognitive strategy.

\subsubsection{Meta-Cognitive Strategies Employed vy Students and Teachers in Teaching Learning English}

The data regarding meta- cognitive strategies were gathered by section 5 of the students' and teachers' questionnaire which contained nine items on a five-point Likert scale. Descriptive statistics was used to portray the percentages, frequencies and means of the items. 


\begin{tabular}{|c|c|c|c|c|c|c|c|c|}
\hline Sn & Item & & 5 & 4 & 3 & 2 & 1 & Mean \\
\hline \multirow[t]{2}{*}{37} & \multirow{2}{*}{$\begin{array}{l}\text { I actively think about what I } \\
\text { have learned in my language } \\
\text { class }\end{array}$} & $S$ & $13(11.8 \%)$ & $20(18.2 \%)$ & $14(13 \%)$ & $40(36.3 \%)$ & $23(20.9 \%)$ & 2.6 \\
\hline & & $\mathrm{T}$ & - & $2(25 \%)$ & - & $4(50 \%)$ & $2(25 \%)$ & 2.6 \\
\hline \multirow[t]{2}{*}{38} & \multirow[t]{2}{*}{$\begin{array}{l}\text { I take diaries on my learning } \\
\text { success and weakness }\end{array}$} & S & $11(10 \%)$ & $20(18.2 \%)$ & $8(7.3 \%)$ & $38(34.5 \%)$ & $33(30 \%)$ & 2.4 \\
\hline & & $\mathrm{T}$ & - & - & - & $4(50 \%)$ & $4(50 \%)$ & 1.5 \\
\hline \multirow[t]{2}{*}{39} & \multirow{2}{*}{$\begin{array}{l}\text { I try to evaluate the } \\
\text { effectiveness of strategies I } \\
\text { use to learn English better }\end{array}$} & $\mathrm{S}$ & $11(11 \%)$ & $24(23.5 \%)$ & $5(4.5 \%)$ & $41(37.3 \%)$ & $32(29.1 \%)$ & 2.5 \\
\hline & & $\mathrm{T}$ & - & $2(25 \%)$ & - & $4(50 \%)$ & $2(25 \%)$ & 1.3 \\
\hline \multirow[t]{2}{*}{40} & \multirow{2}{*}{$\begin{array}{l}\text { When I study information, I } \\
\text { pay much attention to how } \\
\text { well I understand it }\end{array}$} & $\mathrm{S}$ & $21(19.1 \%)$ & $15(13.6 \%)$ & - & $40(36.2 \%)$ & $34(31 \%)$ & 2.5 \\
\hline & & $\mathrm{T}$ & - & - & $1(12.5 \%)$ & $5(62.5 \%)$ & $2(25 \%)$ & 1.9 \\
\hline \multirow[t]{2}{*}{41} & \multirow{2}{*}{$\begin{array}{l}\text { I try to analyze what } \\
\text { difficulty I actually have in } \\
\text { learning English }\end{array}$} & S & $7(6.4 \%)$ & $16(17.3 \%)$ & $9(8.2)$ & $45(40.9 \%)$ & $33(30 \%)$ & 2.3 \\
\hline & & $\mathrm{T}$ & & $2(25 \%)$ & $2(25 \%)$ & $4(50 \%)$ & - & 2.8 \\
\hline \multirow[t]{2}{*}{42} & \multirow{2}{*}{$\begin{array}{l}\text { I set an action plan of how to } \\
\text { solve learning problems or } \\
\text { improve my learning }\end{array}$} & $\mathrm{S}$ & $20(18.2 \%)$ & $19(17.2 \%)$ & $10(9.1 \%)$ & $27(24.5 \%)$ & $34(30.9 \%)$ & 2.7 \\
\hline & & $\mathrm{T}$ & - & $2(25 \%)$ & $2(25 \%)$ & $2(25 \%)$ & $2(25 \%)$ & 2.5 \\
\hline \multirow[t]{2}{*}{43} & \multirow{2}{*}{$\begin{array}{l}\text { I set objectives about the } \\
\text { language skills I need to } \\
\text { improve }\end{array}$} & $\mathrm{S}$ & $22(20 \%)$ & $14(12 \%)$ & $8(7.2 \%)$ & $35(31.8 \%)$ & $33(30 \%)$ & 2.7 \\
\hline & & $\mathrm{T}$ & $5(62.5 \%)$ & $2(25 \%)$ & $1(12.5 \%)$ & - & - & 4.5 \\
\hline \multirow[t]{2}{*}{44} & \multirow{2}{*}{$\begin{array}{l}\text { I plan my schedule so I will } \\
\text { have enough time to study } \\
\text { English }\end{array}$} & $\mathrm{S}$ & $28(27.3 \%)$ & $35(36.4 \%)$ & $11(10 \%)$ & $28(27.3 \%)$ & $6(5.5 \%)$ & 3.4 \\
\hline & & $\mathrm{T}$ & $2(25 \%)$ & $4(50 \%)$ & $2(25 \%)$ & - & - & 4.0 \\
\hline \multirow[t]{2}{*}{45} & \multirow{2}{*}{$\begin{array}{l}\text { After I have learned English, } \\
\text { I think about the way I have } \\
\text { learned it }\end{array}$} & $\mathrm{S}$ & $15(14.5 \%)$ & $11(11 \%)$ & $9(8.2 \%)$ & $34(32.7 \%)$ & $40(40.9 \%)$ & 2.3 \\
\hline & & $\mathrm{T}$ & - & $2(25 \%)$ & - & $4(50 \%)$ & $2(25 \%)$ & 2.3 \\
\hline \multirow{2}{*}{ 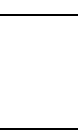 } & \multirow[t]{2}{*}{ Grand mean } & $\mathrm{S}$ & & & & & & 2.6 \\
\hline & & $\mathrm{T}$ & & & & & & 2.7 \\
\hline
\end{tabular}

Table 9: Students' and Teachers' Responses on the Use of Meta-Cognitive Strategies in Teaching- Learning English Keys: Always-5, Usually-4, Sometimes-3, Rarely-2, Never-1, T=Teachers, S=Students

Table-9 illustrates the percentages and frequencies of students' and teachers' responses to the usage of metacognitive strategies in learning English. As can be seen from the data on item 37, 36.3\% and 20.9\% of the students rarely and never respectively think actively about what they learned in language class. However, only $3.7 \%$ of the students indicated that they always and usually think about what they have learned in English class. Similarly, $75 \%$ (50\% rarely and25 \% never) of the teachers reported that they help students practice this reflective exercise. Only $25 \%$ of them indicated that they usually help learners to practice this strategy. Furthermore, $34.5 \%$ and $30 \%$ of the students replied rarely and never respectively concerning taking diaries on their learning success and weakness (item38). Similarly, all of the teachers reported that they rarely ( $50 \%$ ) and never (50\%) encourage students to take diaries.

With regards items $39,66.4 \%$ of the students reported that they rarely $(37.3 \%)$ and never(29.1\%) evaluate the effectiveness of strategies they use to learn English. On the other hand, 50\% and 25\% of the teachers reported that they rarely and never encourage students to reflect on their strategy use. 
The findings items 37,38 and 39 show that students and teachers rarely employ evaluating strategy in the learning process.

Concerning item 40, the majority of the students ( $\mathrm{n}=74)$ indicated that they rarely $(36.2 \%)$ and never (31\%) monitor their comprehension in learning English $(\mathrm{M}=2.5)$. Similarly, $62.5 \%$ of the teachers rarely help learners practice monitoring and $25 \%$ of them never promote this strategy. Similarly, on item 41 more than three-fourth of the students, $(40.9 \%)$ rarely and (30\%) never, analyze what difficulty they have in learning English whereas only $6.4 \%$ and $17.3 \%$ of them do this always and usually respectively. Concerning teachers' responses to this item, while $50 \%$ of them, $25 \%$ usually and 25\% sometimes, help learners to analyze their difficulty in learning English, $50 \%$ of them responded that they rarely do this.

The findings of items 40 and 41 show that both students and teachers rarely employ monitoring strategy in the learning and teaching process.

The aim of item 42 was to find out whether students set an action plan to solve and improve their learning, and whether teachers guide learners towards this direction. For this item, $24.5 \%$ and $30.9 \%$ of the students employ this strategy rarely and never respectively. Similarly, $50 \%$ of the teachers reported that they rarely $(25 \%)$ and never $(25 \%)$ help learners to set an action plan.

Besides, responses to items 43 indicate, 61.8\% (31.8\%rarely and 30\% never) of the students reported that they set objectives about the language skills they need to improve. However, the majority of the teachers usually employ setting goals in their instruction. On the other hand, on item 44 the majority $(n=73)$ of the students indicated that they always (27.3\%) and usually (36.4\%) prepare schedule for studying English. Similarly, $75 \%$ (25\% always and 50\% usually) of the teachers usually help students to plan schedule for studying English.

The findings of items 43 and 44 show that while students employ planning strategy sometimes, teachers usually employ this strategy in their instruction.

Finally, students' responses to item 45 show that while $74.6 \%$ of the students reported that they rarely (32.7\%) and never (40.9\%) reflect on their language learning, only $25.5 \%$ of them responded that they think about what they have learned. On the other hand, $75 \%$ ( $50 \%$ rarely and $25 \%$ never) of the teachers fail to help students think about the way they learn English.

The findings of this item reveal that students lack to use reflection strategy and teachers do not seem to encourage students to employ this strategy. This result is consistent with the findings of item 39 in which case students did not seem to reflect on their strategy use and teachers did not encourage learners to do so.

Generally, the items under meta-cognitive language learning strategy can be grouped into three which include items concerning planning (item 42, 43, and 44), monitoring (item 40 and41) and evaluation strategies (item 37, 38, 39 and 45). The grand mean score of students' responses to items 42,43 , and $44(\mathrm{M}=2.9)$ show that they sometimes employ planning in learning English. Similarly, teachers employed planning strategy in their instruction usually $(\mathrm{M}=3.7)$. However, students rarely use monitoring $(\mathrm{M}=2.4)$ and evaluation strategies $(\mathrm{M}=2.4)$ in learning English. Besides, teachers rarely employ monitoring $(\mathrm{M}=2.4)$ and evaluation $(\mathrm{M}=1.9)$ strategies. The findings of this section show that students and teachers lack employing meta-cognitive strategies in the learning process. The grand mean values on students' (M=2.6) and teachers' ( $M=2.7)$ use of meta-cognitive strategies are less than the average value $(M=3.0)$ on the five-point Likert scale ranging from 1 never to 5 always show the respondents' tendency to employ meta-cognitive strategies rarely (See table 9).

\subsubsection{Open-Ended Question Results}

Three open-ended questions were presented in item number 46, 47 and 48 of the teachers' questionnaire in order to let them express viewpoints freely Appendix B). Item 46 was intended to find out whether the teachers were aware of autonomous learning. It is not expected that teachers promote learner autonomy without being aware of what it means. Four of the teachers did not seem to demonstrate adequate awareness of the issue, for example, one of these teachers defined the term learner autonomy as, "It is necessary learning autonomous subject or language, and I advised them to practice and develop autonomous language." In this statement the expression 'autonomous subject or language' looks vague. Still another in defining the term 'learner autonomy' said, "I think learner autonomy or autonomous learning mean, students learn with interest." The second respondent also did not clearly define the term. From the teachers' responses we can see that they do not have adequate awareness about learner autonomy.

However, four of the teachers could define the term learner autonomy emphasizing that it is a situation in which students' study independently. For example, one of these teachers stated, "The student by himself or herself takes the initiative to learn much more than the teacher tells him/ her." Another teacher said, "The students learn independently, but they should be award about language learning." Therefore, these teachers seem to have shown reasonable understanding of autonomy even though they did not indicate that autonomous learning requires learners to take control of and be responsible for their own learning.

Even though, all the teachers expressed their belief in the essentiality of autonomous language learning, six of them could not justify the rational for learner autonomy properly. For example, one of the teachers in stating the rational for autonomy stated, "Language is governed by law and rule, it needs freedom for communication". Besides still another expressed, "Yes, because it is autonomous language system that makes students better, it is best through autonomous learning." The justifications given are not clear. However, those who showed understanding of the notion of learner autonomy could justify their claims stressing that language learning primarily needs individual efforts and continued practices and that learner autonomy promotes self -confidence. For example, one of these teachers indicated his/her justification as, "Yes, because if students work by themselves, they can achieve more." 
The last question in the teachers' questionnaire was intended to identify their perception of learner autonomy. Five of the teachers stated that students are inadequate in deciding on activities, objectives and materials to learn. Besides, two of the teachers said that they had objectives set by the school which they could not change and that time never allowed them to direct students in this direction. Still the other revealed that he/ she had to shoulder the responsibilities him/ herself since the students were reluctant to involve in decision making.

The findings of the preceding paragraph reveal that teachers perceive their student's incompetent in learning by themselves, and that the teaching learning procedure is already determined by the school and did not involve students in decision making.

From the findings of the open-ended questions we can infer that teacher's inadequate awareness of learner autonomy could be one factor for the inadequate practice in motivating learners towards autonomy (Grad mean=2.8).

\subsubsection{Students' Interview Results}

As mentioned in chapter three, an interview was held with six students using a semi- structured interview schedule. In order to address these themes, the four leading questions presented below were raised with relevant probes.

- Do you involve or do autonomous learning activities such as assignments, projects, group and pair works? If yes, what do students gain by involving in such activities?

- In learning English, do you need your teacher's help all the time? If no, mention the situations in which you need your teacher's help?

- Do you get involved in decision making concerning various aspects of the learning process?

- How do you think about your ability to learn English autonomously? What are your views of learning English by yourself?

In this section, the interviewees ' responses to the above major questions and to respective probes are described, and where possible, an attempt is made to link the findings from the interview, with the results obtained through students' questionnaire.

The first interview question was intended to elicit information pertaining to the interviewees' willingness to involve or do autonomous learning activities such as project works, group and pair works. Four of the students said that they did not want to involve in such activities. They said that such activities were time killing, effortful and demanding. However, only two of them said that they wanted to do autonomous learning activities cooperatively. They said that they could learn from their friends than doing by themselves. This finding is consistent with the findings of the questionnaire in which the majority of the students disagreed $(\mathrm{M}=2.5)$ to practice these activities

The purpose of the second interview question was to elicit information whether students need their teacher's help all the time. Four out of the six interviewed students said that they did not want their teacher's help in learning English all the time. However, they expressed that they need the teacher's help in some situations. For example, when they faced new tasks and activities they could not do, when they wanted to have in depth exploration of the language item they are learning, etc. Here below are quotes from two students concerning their need for help:

Student A: "No, expecting my teacher to render me a help can lead me to be dependent. I need help when

it is difficult for me to comprehend a language".

Student B: "No, I only need my teacher's help when a language task which I have

Been working is really difficult to fully accomplish by myself".

Two of the students; however, showed their interest to be helped by their teachers. One of these students, for example, said, "Yes, the teacher should always be closer to me. I can learn better from my teacher than learn by myself."

Concerning the third interview question on perception of responsibility, more than half of the interviewees considered teachers responsible in decision making related with objective of the English lesson and the materials to be learned, etc. They said that their role was receiving knowledge from the teacher; it is the teacher's job because they are trained and know better than students. For example, student D said, "No, it's the teacher's responsibility to make such decisions. They are trained for such activities".

However, one of the interviewees stated that he/ she likes involving in decision making but the teachers did not allow them to involve in such decision making. For example, here is the report highlighting this:

We are aware of our needs and want to share these needs with teachers. However, they say that they

already have objectives set by the school and they cannot change this. Thus, the lessons become very boring.

The interview results show that four out of the six students did not show interest to involve in decision making and they considered their teacher responsible concerning decision making in the learning process. The result of the interview is consistent with the questionnaire result in which the majority of the students $(\mathrm{N}=56 \%)$ gave responsibility to the teacher (See table 5).

Concerning the fourth interview question which was intended to identify students' perception of their ability in learning English, the majority of them expressed their beliefs that they are competent in learning English by themselves. For example, four of the interviewees said setting aims was not difficult, but two said that they were not able seeming they have no awareness. The questionnaire results gave a mean of 3.8 which is the highest of the students' perceived ability to set goals (See table 6). The interview data show that students believed that they were able to set goals by themselves.

The other interview question in the form of probe was students' perception of their ability to evaluate learning progress. Three of the six interviewees said evaluating progress was no problem, two said it was difficult, and one said that he would have to ask the teacher to test him on writing. The majority of the interviewee expressed their beliefs that they 
were able to evaluate learning progress. This finding is consistent with students' score for their perceived ability to evaluate their own progress ( $\mathrm{M=3.6}$ ) on the questionnaire (See table 6).

Furthermore, the interviewees were asked about their perception of their ability to choose exercise and all the interviewees said that they would have no problem choosing exercise and task to work on if they had the opportunity although one considered this as a difficult activity. There was a mean score of 3.3 for perceived ability to choose exercises and tasks.

Therefore, it can be said that the interview data is consistent with the questionnaire data in which students considered themselves competent.

The last interview question in the form of probe was concerning students perceived ability to evaluate their ability by identifying their weakness and strengths. Four of the interviewees out of six said that evaluating ability was no problem; one said he/ she was not able and one said that he/ she would ask the teacher to evaluate his/ her weakness and strengths; the mean score on the questionnaire for this item was 3.1. Therefore, the result of both the questionnaire and interviewee show that students consider themselves able to evaluate their ability.

Generally, the findings of the interview are consistent with the results found in the questionnaire concerning perception of responsibility and ability. Concerning responsibility perception, the students see the teacher more responsible in learning English. Besides, they perceive themselves able to learn English by themselves. However, they did not want to involve in cooperative learning activities.

\subsubsection{Classroom Observation Results}

In order to find out grade twelve teachers actual classroom practices in promoting learner autonomy, a semistructured observation was conducted using a checklist that consisted of five items with four sub points each (See appendix G, pp. 98). The teachers' activities were observed and rated with categories of 'Yes' or 'No' which were changed into five-point scales namely: Ineffective (0), less effective (1), fairly effective (2), effective (3), and very effective (4)

\begin{tabular}{|c|c|c|c|c|c|c|c|c|c|c|c|}
\hline \multirow[t]{3}{*}{ S.n } & \multirow[t]{3}{*}{ Items } & \multicolumn{10}{|c|}{ Scales } \\
\hline & & \multicolumn{2}{|c|}{4} & \multicolumn{2}{|r|}{3} & \multicolumn{2}{|c|}{2} & \multicolumn{2}{|c|}{1} & \multicolumn{2}{|c|}{0} \\
\hline & & $\mathrm{F}$ & $\%$ & $\mathrm{~F}$ & $\%$ & $\mathrm{~F}$ & $\%$ & $\mathrm{~F}$ & $\%$ & $\mathrm{~F}$ & $\%$ \\
\hline 1 & $\begin{array}{l}\text { Encourage learners to set some } \\
\text { learning goals }\end{array}$ & & & & & & & & & 4 & 100 \\
\hline 2 & Encourage learner responsibilities & & & 1 & 25 & & & 3 & 75 & & \\
\hline 3 & Encourage self-evaluation & & & & & & & 4 & 100 & & \\
\hline 4 & Involve learners in decision making & & & & & 1 & 25 & & & 3 & 75 \\
\hline 5 & $\begin{array}{c}\text { Provide opportunity for strategy } \\
\text { use }\end{array}$ & & & & & 2 & 50 & & & 2 & 50 \\
\hline & Total & & & & $25 \%$ & & & & & & \\
\hline
\end{tabular}

Table 10: Teachers' Actual Classroom Practices of Promoting Learner Autonomy

Keys: 4-Very Effective, 3- Effective, 2-Fairly Effective, 1-Less Effective, 0-Ineffective

The first activity observed was teachers' involvement of learners in setting learning goals. As can be seen from the table in all of the observations none of the teachers were observed promoting goal setting. Therefore, the teachers' practices in relation to this behavior were ineffective.

The second activity observed was teachers' encouragement of responsibility in collaborative work. The observation revealed that almost all the teachers put students in small groups but they did not use activities that require sharing responsibility and they did not encourage or assign students any group roles to which they could be held responsible. However, one of the teachers observed was effective in putting students into groups and assigning them responsibilities. $75 \%$ of the teachers' practices in relation to promoting responsibility were less effective. Therefore, the teachers' practices in relation to this behavior were less effective.

The third activity observed was teachers' encouragement of self-evaluation. All of the teachers were less effective to encourage students' self-evaluation. However, in one of a teacher's class peer correction was encouraged. Therefore, all of the teachers' practices in relation to this behavior were less effective.

The fourth activity observed was teachers' encouragement of learners in decision making. During the observation none of the teachers asked the students to choose from different activities and tasks, letting them decide on their pace of learning, etc. However, only a teacher was observed letting students to choose a friend to work with. 75\% of the teachers' role in relation with this behavior was in effective.

The fifth activity observed was teachers' practice of promoting strategy use. In two of the classes observed teachers were encouraging students to make use of strategies in relation to language skills. However, meta-cognitive strategies were not observed. Therefore, teachers 'practices in relation to this behavior were fairly effective.

Generally, $87.5 \%$ of the teachers' practices in promoting learner autonomy wereless effective and 75\%of them ineffective categories which imply that teachers did not seem to encourage goal setting, responsibility, self-evaluation and decision making. 


\subsection{Discussion}

The first research question was aimed to find out whether students and teacher practices autonomous learning activities in learning English. The majority of the students did not seem to take control of their learning (grand mean on students' practices in learning English by themselves is 2.4). The result shows that students did not seem to exert their efforts to set goals for their learning, and evaluate their learning process. Dickinson (1995:127) characterizes autonomous learners as "those who have the capacity for being active and independent in the learning process; they can identify goals, formulate their own goals, and can change goals to suit their own learning needs and interests. The findings on the students' effort to set learning goals is inconsistent with Dickinson's description of autonomous learners. Similarly, the students did not seem to evaluate their learning. This is inconsistent with Thana soul as (2000) who argues that the analysis of one's strengths and weaknesses, or language learning process is a primary step in a cluster of autonomous learning activities to guide learners to the next stages of their learning process. If learners position themselves in a place where they could assess their skills and knowledge gap and strive to compensate their deficiencies by investing the required time; it is likely for them to succeed in learning English independently. This further gives them a better opportunity to see how much their learning is on a series of progress.

This implies that students lack effort to take control of their learning. This finding is consistent with Mesfin (2008) who studied learner autonomy in learning English at Mekele Yohannes Preparatory School found out students were not exerting effort to improve their English skills and that they were not responsible for their own learning. The main reason for this similarity might be due to the fact that in both of the research settings (both of them being in the same educational system) students were taught in teacher-led classrooms where learners were rendered little support to take control of their learning. The questionnaire data also reveal that students were reluctant to involve in cooperative learning activities $(\mathrm{M}=2.5)$. This is consistent with the findings of the interview which disclosed the fact that the majority of students did not want to involve in cooperative learning activities like group and pair works in which they can practice decision making, planning and evaluating. This suggests that they lack the readiness to take responsibility for their own learning. This finding is inconsistent with what Dickenson (1992: 140) stated, "Students' involvement in cooperative learning activities enable them to be self-motivated and self-regulated learners taking responsibility for their own learning".

Furthermore, the findings show that teachers lack the readiness to promote autonomy (the grand mean for teachers' practices on autonomous learning activities is 2.8). This implies that teachers seemed to lack providing learner choice and sharing responsibility which are keys in the development of learner autonomy. For example, the teacher did not seem to share their responsibility in evaluating students' learning, and involving learners in decision making which traditionally are considered to be the teachers' responsibility. In the development of learner autonomy providing learners with choice for their learning is very important. Teachers can encourage learner set goals and define objectives, and evaluate their learning process by giving them choice in the learning process. The findings of this study imply that teachers did not seem to encourage these autonomous learning activities by encouraging learner choice. Learner choice implies that students can work at their own pace, deciding on questions of what, when, how and how often (Holec, 1987; Williams and Burden, 1997Pierce and Kalkman, 2003). These scholars further confirm that learner choice in making-decisions in learning such as setting objectives, defining contents and progressions, monitoring the procedure, and evaluating the outcome of learning is very important for the development of autonomy. However, the classroom observation reveals that $75 \%$ of the teachers' practices in relation to promoting responsibility and decision making were in effective.

The findings of teachers' practices are not consistent with the findings of the study conducted by Coban (2002) that investigated teachers' practices in promoting learner autonomy in Gazi Preparatory School in Turkish which found out that the teachers were more likely to support ways of developing learner autonomy, particularly in giving choice to learners, self- monitoring and self- evaluation. Furthermore, the result is not consistent with the study conducted by Chung (2005) who examined the motivating style based on teachers' disposition to control students or support their autonomy. The results implied that teachers who were autonomy-supportive to students showed a significant motivating style and intended to support students' intrinsic motivational as well as internalization processes. However, this result was consistent with the study conducted by Tekle (2010) who found out that English teacher at Baso Secondary School lack the commitment to train students to be independent learners through sharing responsibility.

The questionnaire data also show that teachers encourage their students to work cooperatively with other students. Nevertheless, the classroom observation data revealed that teacher' practices in relation to this was not systematic, and approached in unorganized and unplanned ways. For example, the researcher observed that almost all of the teachers were not assigning group members' responsibilities in setting collaborative works.

On the other hand, the result of the open-ended questions showed that four of the teachers could not define the term and failed to justify why learner autonomy is important. The other four of them described learner autonomy but they could not state the rational for promoting learner autono my. This result is consistent with the findings of their practices in promoting autonomous learning activities. From the findings we can infer that teacher's inadequate awareness of learner autonomy could be one factor for their inadequate practices of in encouraging learners towards autonomy. Little (1995) states that learner autonomy depends on teacher autonomy. It is unreasonable to expect teachers to foster the growth of autonomy in their learners if they themselves do not know what it is to be an autonomous learner.

For the second research question, the findings of the Chi-square showed that there was no significant difference between students' and teachers' perceptions of responsibility. The observed Chi-square value $\left(x^{2}=2.86\right)$ shows that there was no significant difference between students' and teachers' perception of responsibility in language learning. That means, both students and teachers considered that teachers were more responsible than students in deciding what will be learnt in the next English class, how long to spend on a given activity, choosing what materials/ activities to use in the 
English class, identifying students' weaknesses and strengths in learning English,making sure students make progress during English lesson and evaluating learning performance which were related to formal language instruction. However, only in one of the eight items both students and teachers had the notion of shared responsibility to correct students' mistakes in learning English. The findings of interview with students also confirm that students consider teachers more responsible. Four of the interviewed students out of six gave responsibility to their teachers concerning decision making in learning English.

The findings of responsibility perception are inconsistent with Wenden's (1991) claim that autonomous learners exercise choice of materials, methods and tasks for their learning. Similarly, teachers' unwillingness to share responsibility with students does not support what Voller (1997) suggested, that the teacher should share responsibilities concerning decision making with learners so as to develop sense of responsibility in the learners. These results are; however, consistent with a study conducted by Kuram (2009) in the field which investigated the perceptions of preparatory students and teachers regarding responsibilities and abilities related to autonomous learning. The findings of this study were that students do not take responsibility for their learning although they have the ability and teachers themselves take on most of the responsibilities by perceiving their student's incapable of fulfilling their responsibilities. The teacher's traditional role as decision maker may be the reason for students to give much responsibility to teachers than themselves

The findings of ability perceptions revealed that there is a significant difference between students and teachers. Students perceive themselves capable $(\mathrm{M}=3.3)$ in several areas such as setting objectives, making choices and monitoring their progress. The results of the interview also showed that the majority of students evaluated their ability in learning English positively. They believe that they have the ability to take control of their learning but they failed to practice autonomous learning and share responsibility with the teacher. However, the mean score on students' practices of autonomous learning $(\mathrm{M}=2.4)$ indicate their low performance of autonomous learning. On the other hand, teachers considered students incompetent $(\mathrm{M}=2.3)$ to take control of their own learning. This shows that teachers are not ready to share responsibility with students.

The third research question was aimed at finding out the language learning strategies used by students and employed by teachers in their instructions.

Autonomous learners are able to monitor their own learning. In doing so, they use learning strategies. Cognitive strategies enable learners to manage the learning process as well as learning materials through direct ways (Oxford, 1990). Strategies such as elaboration, resourcing, summarizing and note-taking were included in this study. The result of the descriptive statistics indicated that both students and teachers valued the use of resourcing and elaborating followed by note-taking and summarizing in which both groups of respondents reported the frequency of their strategy use on a five-point Likert scale. The most frequently used strategies were resourcing and elaboration. The result of employing elaboration strategy is consistent with a study conducted by Chamot (1989). Students (grand mean=3.5) and teachers (grand mean=3.8) reported that they usually employ cognitive strategy in the learning process.

Concerning the meta-cognitive strategies employed, the results of the descriptive statistics displayed that while students sometimes use planning which involves learners through autonomous self-management of time and learning process, teachers most frequently employed this strategy in their instruction. The result of this strategy use by students was inconsistent with previous study by (Chien, 2004) which found out that the most frequently used strategies were planning strategies. This study also revealed that monitoring and evaluation strategies were appeared to be employed by the students and teachers least frequently. This finding is consistent with the study conducted by Cotterall (1999) who investigated the language learning beliefs of a group of students with the help of a survey and the result indicated that the use of two strategies 'monitoring and evaluating' were quite limited.

In the study, cognitive strategy was reported to be used more frequently than meta-cognitive, and the most frequently used strategies among meta-cognitive strategy were planning strategies. The findings of cognitive and metacognitive language learning strategies are consistent with the study conducted byJohnes (1995) who investigated learning strategies used by foreign language students and their teachers

\section{Summary, Conclusion and Recommendations}

This chapter deals with the summary of the findings, conclusions, recommendations of alternative solutions for promoting learner autonomy based on the findings of the study

The purpose of this study was to examine grade twelve students' and their teachers' perception and practice in the development of learner autonomy at Emdibr Preparatory School. In order to achieve this objective, the following research questions were formulated:

- Do grade twelve students and teachers at Emdibir Preparatory School practice autonomous language learning activities in the teaching -learning process?

- Is there significant difference between the students' and teachers' perceptions of learner autonomy (responsibility and ability perception) in learning English at Emdibir Preparatory School?

- Do the students and teachers employ language learning strategies (cognitive and meta-cognitive strategies) in the teaching-learning process at the school in focus?

In the course of answering these questions, descriptive survey method was employed. To this effect questionnaire, interview and classroom observation were utilized as instrument during data collection. Simple random sampling was used to select 112 subjects (70 male and 42 female) out of 398 student population. Eight grade twelve teachers were included in the study. Accordingly, these informants participated and provided dependable data. Furthermore, the obtained data were analyzed by employing statistical tools such as frequency, percentage, mean, Chi-square and independent sample t-test using SPSS window 15 software. 


\subsection{Summary of the Major Findings}

The major findings of the study are summarized as follow:

- Students' and teachers' responses concerning their practices ( $M=2.4$ and $M=2.8$ for students and teachers respectively)show that students did not seem to exert effort in involving autonomous learning activities such as goal setting, evaluating learning and collaborative learning. The interview data show that five out of the six interviewed students did not want to do autonomous learning activities. Similarly, the teachers did not seem to encourage learners to do these activities and tasks by themselves.

- Teachers of this study did not show awareness of learner autonomy in learning English.

- The result of classroom observation revealed that $87.5 \%$ of the teachers' practices in promoting learner autonomy were less effective and $75 \%$ of them were ineffective which show that teachers did not seem to encourage goal setting, responsibility, self-evaluation and decision making, and this is consistent with the result of the teachers' questionnaire concerning their practices of promoting learner's autonomy.

- While $51.1 \%$ and $59.4 \%$ of the students and teachers respectively gave more responsibility to the teacher, $34.9 \%$ and $30 \%$ of the students and teachers respectively had the notion of shared responsibility. Only $14 \%$ and $10 \%$ of the students and teachers respectively gave responsibility to the students in learning language. The interviewee data also indicated that four out of six interviewed students considered their teachers more responsible concerning decision making in the learning process. The result of the $2 \times 3$ contingency table Chi-square concerning the difference in perception of responsibility between students and teachers $\left(x^{2}=2.86\right)$ did not indicate significant difference.

- While the students consider themselves able (the grand mean value on their perception of ability is 3.3) to set goals, plan their learning, decide on what work to do and evaluate their learning performance, teachers (grandmean value on their perception of ability is 2.3 ) believed that students' ability was poor. The result of the independent sample t-test between teachers' and students' perception of ability in language learning is $3.34, \mathrm{p}=$ 0.00 .

- The grand mean values of students and teachers in employing cognitive strategies are 3.5 and 3.8 respectively which indicate that they usually employ this strategy. Elaboration $(\mathrm{M}=3.6)$ and resourcing $(\mathrm{M}=3.6)$ were the most frequently employed cognitive strategies by the students followed by note-taking $(\mathrm{M}=3.5)$ and summarizing $(\mathrm{M}=3.2)$. On the other hand, teachers reported employing resourcing $(\mathrm{M}=4.5)$ followed by note-taking, $(\mathrm{M}=4.3)$ elaboration ( $\mathrm{M}=3.5)$ and summarizing $(\mathrm{M}=3.3)$ strategies frequently in their instruction.

- While students employ planning (grand mean=2.9) in learning English sometimes, teachers employ planning (grand mean=3.7) strategy in their instruction usually. However, students use monitoring (grand mean=2.4) and evaluations (grand mean=2.4) strategies rarely in the learning process. Besides, teachers rarely employ monitoring (grand mean=2.4) and evaluation (grand mean=1.9) strategies in their instruction.

\subsection{Conclusions}

Based on the findings and discussions made in this study, the following conclusions were made.

- Grade twelve students at Emdebir Preparatory and Comprehensive Secondary School do not seem to involve in tasks and activities that promote their autonomy. Similarly, grade twelve teachers of the school lack using autonomy supporting practices. They lacked to involve learners in making decisions related to their own learning, and did not seem to encourage learner choice by helping students to learn at their own pace. This might be due to their lack of awareness about learner autonomy.

- There is similarity between students and teacher's perception of responsibility in learning English. Both students and teachers considered that teachers were more responsible in making decision related to formal language instruction, such as deciding what and how to learn and evaluate learning performance. The teachers see themselves as taking almost all responsibility because they perceive students lack the ability to take responsibility in language learning process.

- The fact that teachers consider students incompetent to take responsibility for their learning might be one factor for teachers' inadequate autonomy supportive practices.

- The students and their teachers usually employ cognitive strategies in the instructional process.

- While the students sometimes tend to plan their learning, their teachers help them practice this strategy in the learning process. However, the students and their teachers rarely employ monitoring and evaluatingmetacognitive strategies.

- Generally, the results indicate that even though students perceive themselves positively, they are unwilling to take responsibility and control their learning, and that they continue to see the teacher as a dominant figure who is the decision maker in the classroom. On the other hand, teachers lack the ability to move their students towards autonomous learning.

\subsection{Recommendations}

On the basis of the findings and the conclusions drawn out of them, the following recommendations were made. In order to help students to become autonomous learners of English obviously English language teachers must have awareness of learner autonomy. Therefore, the department of English at the target school should organize regular awareness raising workshops to enable English language teachers to be aware or reinforce their understanding of the 
value of independent language learning, to be prepared to assume new roles in the classroom, to prepare contents and classroom tasks that incorporate components of autonomous learning.

Autonomous learning has to be understood and accepted as a goal not only by students but also by teachers to insure its meaningful realization. Besides, English teachers should provide learners with choice based on their needs and involve them in decision-making in their learning so that their motivation is enhanced.

Teachers also need to experience autonomous learning themselves and need to be committed to self-monitoring development since teachers who cannot develop their own autonomy, are unable to develop their students' autonomy in learning.

In addition, English language teachers should counsel students to take full responsibility and increase commitment for their learning. Thus, English teachers, who are in frequent contact with students, had better help the latter to become aware of the worth of autonomous learning.

Autonomous learning can hardly be conceived unless the learners play the roles of planning, monitoring and evaluating their learning. Therefore, English language teachers need to delegate to their students' tasks such as setting goals for learning, selecting materials to be used in the classroom, reflecting on their learning success or difficulties, developing action plan of how to improve learning, evaluating their learning progress, choosing tasks to be done, etc.

Finally, empirical investigations need to be made on ways of employing learner training in order to develop learner autonomy.

\section{Acknowledgement}

My heartfelt appreciation goes to Emdebir Secondary School Principal Mr. Mulugeta Teka, for his marvelous help during the study. I am especially grateful to my wife for standing by my side in substantiating the research work at each step of the study. I would also like to thank W/ rt Kuku Deg if for typing the manuscript

\section{References}

i. $\quad$ Allwrigh, R (1987). Why do we want teaching materials for? ELT Journal, 36(2), 8-13.

ii. Aoki, N and Smith, R.C (1999). Learner Autonomy in Cultural Context. In Catterall,S. and Creabble,D.(Eds). Learner Autonomy in Language Learning. Defining the field and effecting change. Frankfurt: Peter Lang.

iii. Ataklti Teklehimanot, (1998). An Exploration of Promotion of Learner Autonomy in the EFL

iv. Teaching and Learning Practices at AAU freshman level: AAU. Unpublished MA Thesis

v. Atkins, A. Hailom, B. and Nuru, M. (1996).Skills Development Methodology Part II. Addis Abeba: Addis Ababa University Press.

vi. Benson, P. (2001). Teaching and Researching Autonomy in Language Learning. London:

vii. Longman.

viii. Benson, P.andVoller, P (Eds.) (1997). Autonomy and Independence in Language Learning. London: Longman

ix. Blue, G.M. (1988).Self- assessment: The Limits of the Learner Independence. In Brookes, A. and Grud, P.(Eds.) Individualization and Autonomy in Language Learning ELT Documents. Durban: Modern English Publications and the British Council.

x. Brown, H.D. (2007). Principles of Language Learning and Teaching (5th Ed).New York: Pearson Education, Inc.

xi. Boekaerts, M.(1997).Self-Regulated Learning: A new concept embraced by Researchers, Policy-makers, Educators, Teachers and Students. Learning and Instruction, 7 (2), 161-186.

xii. Boud, D. (1988). Moving toward Autonomy. London: Kogan Page.

xiii. Catterall, S. and Crabbe, D. (eds) (1999). Learner Autonomy in Language Learning: Defining the Field and Effecting Change.Frankfurt: PETER LANG.

xiv. Catterall, S. (1 995).A Course for Learner Autonomy.ELT Journal, 49(3), 219-236.

xv. Chan,V. (2001). Readiness for Learner Autonomy: What do our learners tell us? Teaching in Higher Education, 6(4), 505-518.

xvi. Chan,V. Spratt.M. and Humphreys, G. (2010). Autonomous Language Learning.Hong Kong Tertiary Students' Attitude and Behaviors. Evaluation and Research in Education, 16(1), 1-18. Retrieved from http:// WWW. Information World. Com

xvii. Clark, J.L. (1987). Curriculum Renewal in Schools of Foreign Language Learning. Oxford:

xviii. Oxford University Press.

xix. Cole, P. G. and Chan L. K.S. (1994).Teaching Principles and Practices.Australia:

xx. Prentice Hall.

xxi. Cook, V. (1993). Linguistics and Second Language Acquisition. London: Macmillan.

xxii. Crabbe, D. (1999). Learner Autonomy in Language Learning: Defining the Field and Effecting Change. Frankfurt: Peter Lang.

xxiii. Crabbe, D. (1999). Working with Teachers. In Catterall, S. and Crabbe, D. (eds.) Learner Autonomy in Language Learning: Defining the Field and Effecting Change. Frankfurt: Peter Lang

xxiv. Crandall, J. (1999). Cooperative Language Learning and Affective Factors.In Arnold, J. (Eds.).Affect in Language Learning. (pp.226-245). Cambridge: Cambridge University Press.

xxv. Cotterall, S. and Crabble, D. (1993). Learner Autonomy in Language Learning: Defining the Field and the Effective Change. Berlin: Peter Lang.

xxvi. Cresswell, J.W. (2003). Research Design: Qualitative, Quantitative and Mixed Methods Approach. New Delhi: Sage Publishers. 
xxvii. Cunnings Worth, A. (1995).Choosing Your Course Book. London: Heinemann.

xxviii. Cunnings Worth, A. (1984).Evaluating and Selecting ELT Teaching Materials. London: Heinemann

xxix. Dam, L. (1990). Learner Autonomy in Practice.In Gathercole, L, (1990). Great Britain: Bourne Press.

xxx. Dan, L. and Legenhouse, L. (1996). The Acquisition of Vocabulary in Autonomous LearningEnvironment the first Months of Beginning English. Hong Kong: Hong Kong University Press Retrieved from http:/ WWW./ las.Ac.uk./ resources p. / 1409/

xxxi. Deci, E. L, and Ryan, R. M. (1985).Intrinsic Motivation and Self-determination in Human

xxxii. Behavior. NY: Plenum Press

xxxiii. Dickinson, L. (1987). Self -instruction in Language Learning. Cambridge: Cambridge University press.

xxxiv. Dickinson, L. (1988). LearnerTraining. In Brokes, A and Grundy,P.(Eds). Individualization and Autonomy in Language Learning ELT documents 131. Durban: Modern English Publications and the British Council

xxxv. $\quad$ Dickinson, L. (1993). Talking Shop: Aspects of Autonomous Learning.ELT Journal, 47 (1), 330-341

xxxvi. Dickinson, L. (1995). Autonomy and Motivation.ELT Journal, 23 (2), 165-189

xxxvii. Dornyei, Z. (2001). Teaching and Researching Motivation. Harlow: Longman

xxxviii. Dornyei, Z (2005).The Psychology of the Language Learner: Individual differences in second language acquisition. MAHAWAH: Lawrence Erboum Associate publishers.

xxxix. Gay, L.R. and Airasian, P. (1996).Educational Research: Competencies for Analysis and Application. USA: PrenticeHall,Inc.

xl. Holec, H. (1981). Autonomy and Foreign Language Learning. Oxford: Pergamon.

xli. Holec,H.(1987). The Learner as a Manager: Managing learning or managing to learn? In Wenden, A. and Rubin, J. (Eds.). Learner Strategies in Language Learning. Prentice Hall: International (UK) Ltd.

xlii. Hedge, T. (2000). Teaching and Learning in the Language Classroom. Oxford: OUP.

xliii. Jones, J. (1995). Self-access and Culture. ELT Journal 49(3), 228-234.

xliv. Kuram, U. (2009). Autonomy in Language Learning: Do Students Take Responsibility for their

xlv. Learning? Journal of Theory and Practice in Education.

xlvi. http:/ / eku.comu.edu.tr/ index/ 5/ 2/ e ustunluoglu.pdf, 5 (2):148-169.

xlvii. Lee, I. (1991). Supporting Greater Autonomy in Language Learning.ELT Journal, 52(4), 282-288.

xlviii. Little, D. (1991).Learner Autonomy 1: Definitions, issues and problems. Dublin: Authentic.

xlix. Little, D. (1995). Learning as dialogue: the dependence of learner autonomy on teacher autonomy. ELT Journal, 23, $175-181$.

1. Littlewood, W. (1999).Defining and Developing Autonomy in East Asian Contexts.ELT Journal,20 (1), 71-94.

li. McDonough, S. (1995).Strategy and Skills in Learning a Foreign Language. London: Edward Arnold.

lii. MesfineEyobe.(2008). Learner Autonomy in Learning English: Mekele Atse Yohannes Preparatory School in Focus: AAU. Unpublished MA Thesis.

liii. Nunan, D. (1988). The Learner-centered Curriculum. Cambridge: Cambridge University Press

liv. Nunan, D. (1989). Designing Tasks for the Communicative Classroom: A Study in Second Language Teaching. New York: Cambridge University Press.

lv. Nunan, D. (1997). Designing and adapting materials to encourage learner autonomy. In P. Benson and P. Voller (eds) Autonomy and Independence in Language Learning. London: Longman.

lvi. Nuru-RazikMaru.(2006). A Study of the Practice of Autonomous Learning in Teachers

lvii. Education with Particular Reference to Bahirdar University: AAU. Unpublished MA

lviii. Thesis.

lix. Richards,J.C.(1997). The Dialema of Teacher Education in Second Language Teaching. In Richards, J. and Nunan, D. (Eds.).Second Language Teacher Education. Cambridge: Cambridge University press.

lx. Spratt, M., Humphreys, G., Chan, V. (2010). Autonomy and motivation: Which comes first?

lxi. $\quad$ Language Teaching Research Journal, 6, 245-266.

lxii. Scharle, A. and Szabo, A. (2000). Autonomy in language learning: A guide to developing learner responsibility. Cambridge: Cambridge University Press.

lxiii. Sharp, C. (2002). Study Support and the Development of the Self-regulated Learner. Journal of

lxiv. Educational Research, 44 (1), 29-41.

lxv. O'Malley, J. M. and Chamot, A. U. (1990). Learning Strategy in Language Acquisition. New York: Cambridge University Press.

lxvi. Onozawa, C. (2010). Promoting autonomy in the language class and how autonomy can be applied in the language class. Journal Article, vol.4.

lxvii. Oxford, R. (1990). Language Learning Strategies. What Every Teacher Should Know. Boston: Heinle and Heinle Publishers. Pierce, W.J and Kalkman, L.D. (2003). Applying Teacher-centered Principles in Teacher

lxviii. Education: Theory into Practice. Journal of Taylor and Francis, (42), 27-58.

lxix. Payne, G.and Payne.J. (2004).Key Concepts in Social Research (2nd Ed.). New Delhi: SAGE Publishers

lxx. Thanasoulas, D. (2000). What is learner autonomy and how can it be fostered? The Internet TESL Journal, 6(11).Retrieved on September 30, 2010, from http:/ / WWW.itesl/ j.org/ Articles/ Thanasoulas- autonomy.html.

lxxi. Tekle, Ferede (2010). Hinderances to the development of autonomy among grade nine students and teachers in learning English: Baso General Secondary School in focus: AAU. Unpublished MA Thesis.

lxxii. Tudor, I. (1993). Teacher roles in the learner-centered classroom.ELT Journal, 47 (1), 23-24.

lxxiii. Ushioda, E. (1996). Learner Autonomy: The Role of Motivation. Dublin: Authentic Ltd. 
lxxiv. Utman, C. H. (1997). Performance effects of motivational state: A meta-analysis Personality and Social Psychology Review. ELT Journal 1, 170-182.

lxxv. Voller, P. (1997). Does the Teacher have a Role in Autonomous Language Learning?Autonomy and Independence in Language Learning. London: Longman.

lxxvi. Wenden, A.and Rubin, J. (eds.). Learner Strategies in Language Learning. Prentice Hall: International (UK) Ltd.

lxxvii. Wenden, A. (1991). Learner Strategies for Learner Autonomy. Prentice Hall: International (UK) Ltd.

lxxviii. White, C. (1995). Autonomy and Strategy Use in Distance Foreign Language Learning: ResearchFindings. EFL Journal, 23 (2), 207-221.

lxxix. William, M. and Burden, R.L. (1997). Psychology for Language Teachers: A Social Constructionist Approach.UK: Cambridge University Press.

lxxx. Zimmerman, B.J. (1998). Developing Self-fulfilling Cycles of Academic Regulation: AnAnalysis Of Exemplary Instructional Models. New York: Guilford Press.

\section{Appendix}

Questionnaire in English for Students

A Questionnaire to be filled out by Grade Twelve Students

Dear Students,

The purpose of this questionnaire is to gather data useful for a research on Learner Autonomy in Language Learning: perception and practice. (Grade Twelve Students and Teachers at Emdibir Preparatory School in Focus). The questionnaire is designed to find out your perceptions and practices of learner autonomy. The success of the study is unquestionably dependent on your genuine responses. Therefore, you are kindly requested to respond to each item in the questionnaire honestly and carefully based on your experience and belief. Your responses will be kept with maximum confidentiality and, thus, there is no need to write your name.

Thank you for your valuable time and cooperation

Part-One: Personal Information

Directions: Insert the Relevant Information in Each Blank Space

Sex: ---------------School NameGrade-

Part-Two

General directions: This questionnaire comprises six sections. Please read the instructions given at the top of every table before you respond to the items.

For items 1-15 in the table below in section 1 are accompanied with five options: Strongly Agree, Agree, Undecided, Disagree and Strongly Disagree. Respond to these items by putting a tick mark $(\sqrt{ })$ in the appropriate box.

\begin{tabular}{|c|c|c|c|c|c|c|}
\hline \multirow[t]{2}{*}{ S.n } & \multirow[t]{2}{*}{ Items } & \multicolumn{5}{|c|}{ Responses } \\
\hline & & 5 & 4 & 3 & 2 & 1 \\
\hline 1 & I set goals by myself in learning English & & & & & \\
\hline 2. & I set goals on improving the grade/ score I previously earned in English & & & & & \\
\hline 3 & I plan what activities to do in learning English & & & & & \\
\hline 4 & I note what I have learned and achieved after each reading lesson & & & & & \\
\hline 5 & I judge the effectiveness of activities, topics and materials I do in the English classroom & & & & & \\
\hline 6 & I try to figure out solutions to problems in learning English by myself & & & & & \\
\hline 7 & I wait until the teacher helps me to seek out solutions for learning problems & & & & & \\
\hline 8 & I do not evaluate my language learning progress & & & & & \\
\hline 9 & I discuss my language learning progress with a friend & & & & & \\
\hline 10 & I set goals about the tasks and exercises I need to study in learning English & & & & & \\
\hline 11 & I plan how much Vocabulary I need to study a day for studying language learning skills by myself & & & & & \\
\hline 12 & I think about how I can learn better to suit my learning styles & & & & & \\
\hline 13 & I organize my own learning even if the teacher is not there & & & & & \\
\hline 14 & I work cooperatively with other students & & & & & \\
\hline 15 & I involve in autonomous learning activities like project wok & & & & & \\
\hline
\end{tabular}

Table 11: Section-One: Activities And Tasks

Keys:5=strongly agree, $4=$ agree, $3=$ neither agree nor disagree, $2=$ disagree, $1=$ strongly disagree 
The following items are devised to identify your perception of responsibility in language learning. For items 16-23 please put a tick mark $(\sqrt{ })$ where appropriate in the box below.

\begin{tabular}{|l|l|l|l|l|}
\hline S.n & \multicolumn{1}{|c|}{$\begin{array}{c}\text { When you are learning English, whose } \\
\text { responsibility should it be? }\end{array}$} & $\begin{array}{c}\text { Teachers ' } \\
\text { responsibility }\end{array}$ & $\begin{array}{c}\text { Both teachers' and } \\
\text { students' responsibility }\end{array}$ & $\begin{array}{c}\text { Students' } \\
\text { responsibility }\end{array}$ \\
\hline 16 & Deciding the objectives of the English lesson & & & \\
\hline 17 & $\begin{array}{l}\text { Deciding what will be learnt in the next } \\
\text { English class }\end{array}$ & & & \\
\hline 18 & Deciding how long to spend on each activity & & & \\
\hline 19 & $\begin{array}{l}\text { Choosing what materials/ activities to use in } \\
\text { the English class }\end{array}$ & & & \\
\hline 20 & $\begin{array}{l}\text { Identifying students' weaknesses and } \\
\text { strengths in learning English }\end{array}$ & & & \\
\hline 21 & $\begin{array}{l}\text { Making sure students make progress during } \\
\text { English lesson }\end{array}$ & & & \\
\hline 22 & Evaluating students' abilities & & & \\
\hline 23 & $\begin{array}{l}\text { Correcting students' mistakes in learning } \\
\text { English }\end{array}$ & & & \\
\hline
\end{tabular}

Table 12: Section-Two: Responsibility perceptions

This questionnaire was devised to determine how you see your ability in learning English. So, for items 24- 30 please put a tick mark $(\sqrt{ })$ where appropriate in the box below.

\begin{tabular}{|c|c|c|c|c|c|c|}
\hline \multirow{2}{*}{ S.N } & Items & \multicolumn{5}{|c|}{ Responses } \\
\hline & In learning English, how good do you think you are in the following situations? & 5 & 4 & 3 & 2 & 1 \\
\hline 24 & Carry out learning goals & & & & & \\
\hline 25 & Plan work in learning English & & & & & \\
\hline 26 & Learn successfully without teacher supervision & & & & & \\
\hline 27 & Make choices about what work you want to do & & & & & \\
\hline 28 & Choose the exercises and tasks I work on & & & & & \\
\hline 29 & Evaluate your learning abilities & & & & & \\
\hline 30 & Test yourself to see how much you have learned & & & & & \\
\hline
\end{tabular}

Table 13: Section-Three: Perception of Ability

Keys5 = very good, $4=$ good, 3 = uncertain, 2 =poor, $1=$ very poor

For items 31-45 please put a tick mark $(\sqrt{ })$ where appropriate in the box below. In learning English, how often do you do the following? 


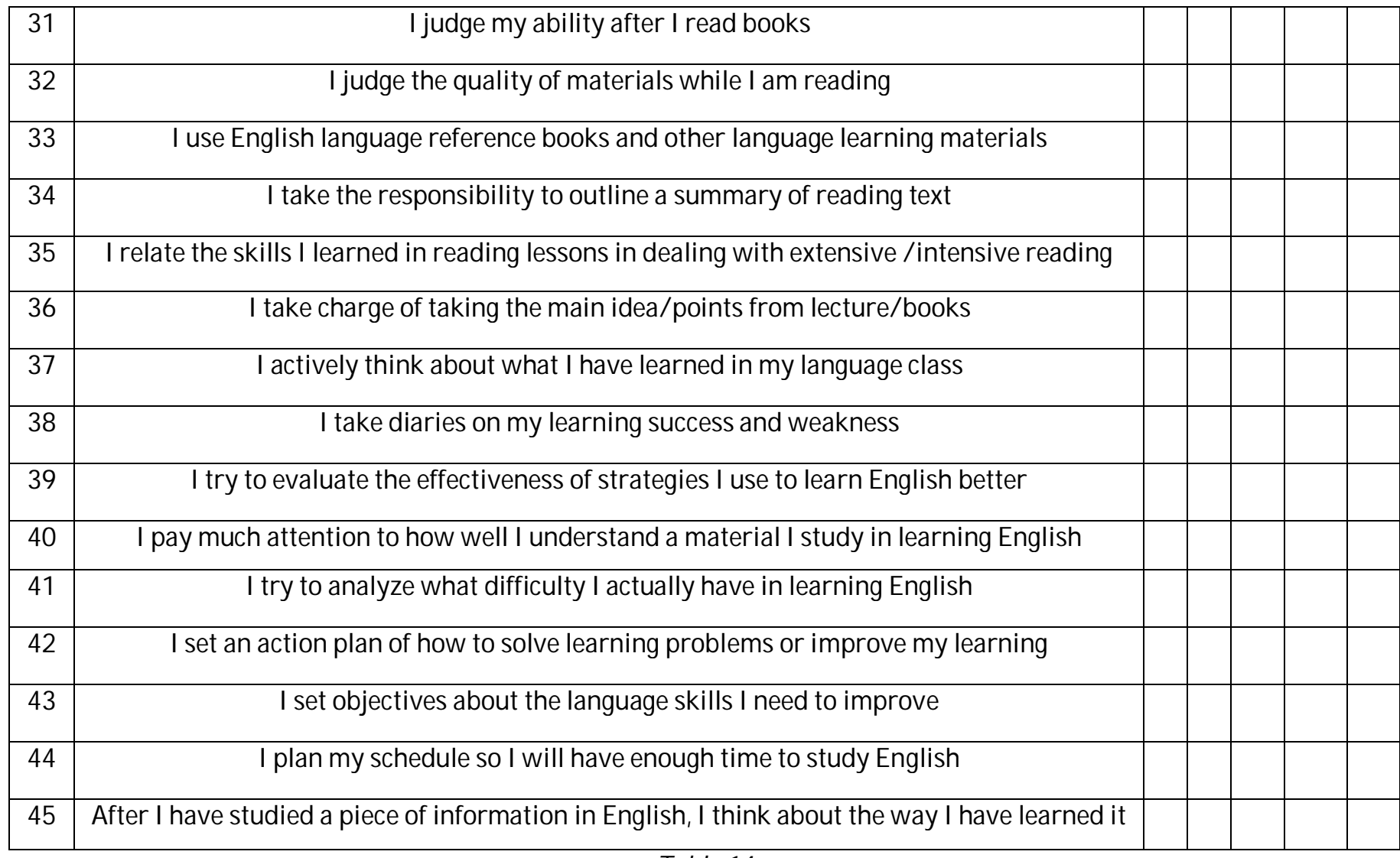

Table 14

Keys $5=$ always $4=$ usually $3=$ sometimes $2=$ rarely $1=$ never

Questionnaire for Teacher

A Questionnaire to be Filled Out by Grade Twelve English Teachers

Dear teachers,

The purpose of this questionnaire is to gather data useful for a research on Learner Autonomy in Language Learning: perception and practice. (Grade Twelve Students and Teachers at Emdebir Preparatory School in Focus. It is prepared to investigate your perception of learner autonomy and actual practices of promoting autonomous learning. The success of the study is unquestionably dependent on your genuine responses. Therefore, you are kindly requested to respond to each item in the questionnaire honestly and carefully based on your experience and belief about learner autonomy. Your responses will be kept with maximum confidentiality and, thus, there is no need to write your name.

Thank you for your valuable time and cooperation

Part-One: Personal Information

Directions: Insert the relevant information in each blank space

Sex: ------------School Name----------------------Experience in teaching English------

Part-Two

Section-One: Items 1-15 in the table below are accompanied with five options: Strongly Agree, Agree, Undecided, Disagree and Strongly Disagree. Respond to these items by putting a tick mark $(\sqrt{ })$ in the appropriate box.

\begin{tabular}{|c|c|c|c|c|c|c|}
\hline \multirow[t]{2}{*}{ s.n } & \multirow[t]{2}{*}{ Item } & \multicolumn{5}{|c|}{ Responses } \\
\hline & & 5 & 4 & 3 & 2 & 1 \\
\hline 1 & I encourage learners to set goals for their own learning & & & & & \\
\hline 2. & I help learners set goals on improving their English results/ scores & & & & & \\
\hline 3 & I encourage students to plan what activities to do in learning English & & & & & \\
\hline 4 & $\begin{array}{l}\text { I help learners to note what they have learned and achieved after each } \\
\text { reading lesson }\end{array}$ & & & & & \\
\hline 5 & $\begin{array}{l}\text { I help learners to judge the effectiveness of activities, topics and materials } \\
\text { they do in the English classroom }\end{array}$ & & & & & \\
\hline
\end{tabular}




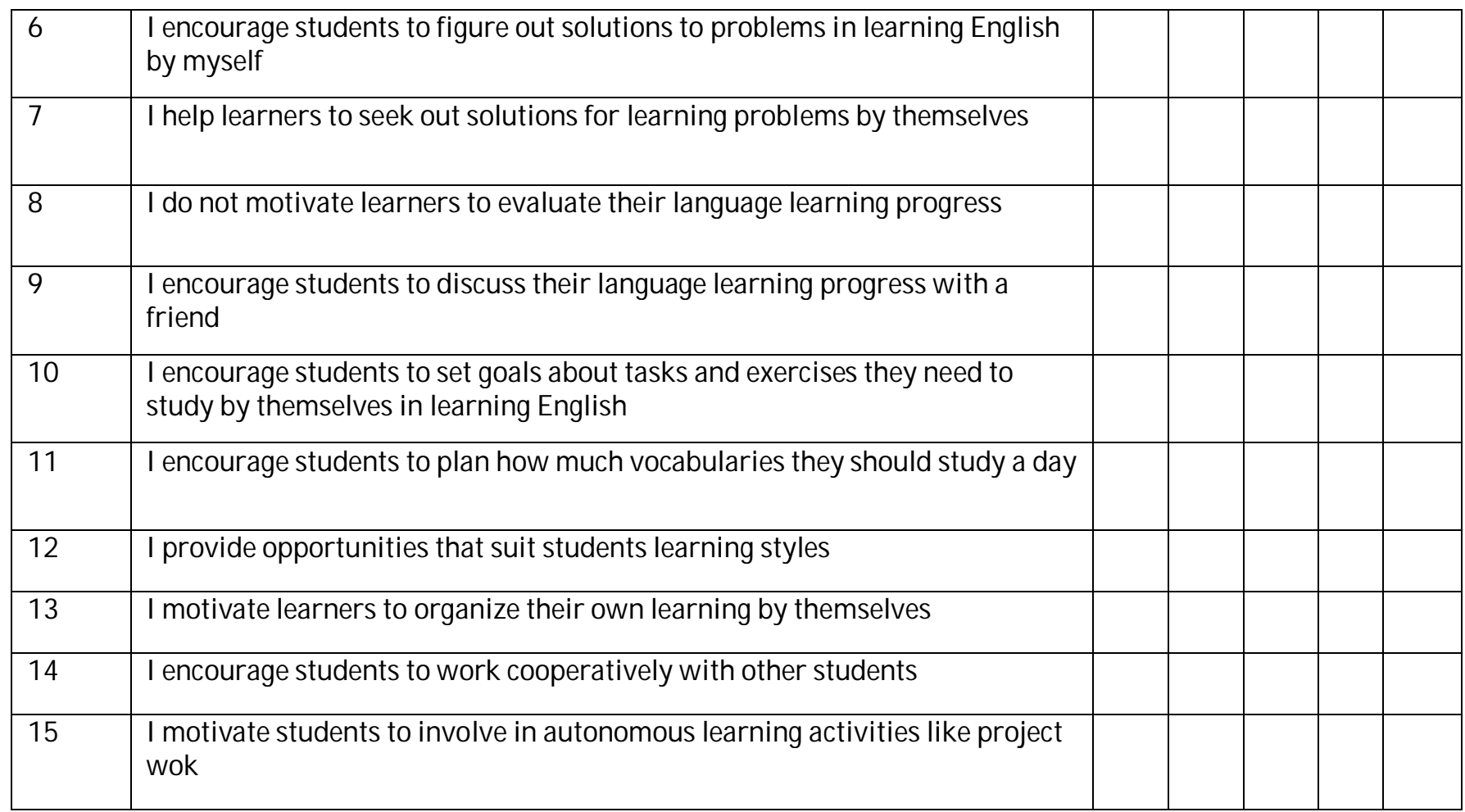

Keys5 $=$ Strongly Agree 4=Agree3=Undecided2=Disagree1 = Strongly Disagree

\section{Section-one: Practices for promoting Learner Autonomy}

This questionnaire was devised to determine how you see responsibilities in learning English. So, for items 16-23 please put a tick mark $(\sqrt{ })$ where appropriate in the box below.

\begin{tabular}{|c|l|c|c|c|}
\hline $\begin{array}{l}\text { S. } \\
\mathbf{n}\end{array}$ & $\begin{array}{l}\text { In teaching and learning English, whose responsibility } \\
\text { should it be? }\end{array}$ & $\begin{array}{c}\text { Teacher's } \\
\text { responsibilit } \\
\text { y }\end{array}$ & $\begin{array}{c}\text { Both teacher's } \\
\text { and student's } \\
\text { responsibility }\end{array}$ & $\begin{array}{c}\text { Student's } \\
\text { responsibility }\end{array}$ \\
\hline 16 & $\begin{array}{l}\text { Identifying students' weaknesses and strengths in } \\
\text { learning English }\end{array}$ & & & \\
\hline 17 & Deciding the objectives of the English lesson & & & \\
\hline 18 & Deciding what will be learnt in the next English class & & & \\
\hline 19 & Deciding how long to spend on each activity & & & \\
\hline 20 & $\begin{array}{l}\text { Choosing what materials, activities and method to use } \\
\text { in the English class }\end{array}$ & & & \\
\hline 21 & Making sure students ' progress in learning English & & & \\
\hline 22 & Evaluating students' learning abilities & & & \\
\hline 23 & Correcting students' mistakes in learning English & & & \\
\hline
\end{tabular}

\section{Section-Two: Responsibility perception}

\section{Section-Three: Perception Ability}

This questionnaire was devised to determine how you see your students' ability in learning English. So, for items 24- 45 please put a tick mark $(\sqrt{ })$ where appropriate in the box below.

\begin{tabular}{|l|l|l|l|l|l|l|}
\hline \multirow{2}{*}{ s.n } & \multicolumn{1}{|c|}{ Items } & \multicolumn{3}{|c|}{ Responses } \\
\cline { 2 - 6 } & In learning English, how good do you think your students are in the following situations? & 5 & 4 & 3 & 2 & 1 \\
\hline 24 & Carry out their own learning goals & & & & \\
\hline 25 & Plan their work in learning English & & & \\
\hline
\end{tabular}




\begin{tabular}{|l|l|l|l|l|l|}
\hline 26 & Learn successfullywithout teacher supervision & & & \\
\hline 27 & Make choices about what work they want to do & & & \\
\hline 28 & Choose the exercises and tasks they work on & & & \\
\hline 29 & Evaluate their learning abilities & & & & \\
\hline 30 & Test themselves to see how much they have learned & & & \\
\hline
\end{tabular}

Keys5 = very good, 4 =good, 3 = uncertain, 2=poor, 1 =very poor

\section{Section-Four}

For items 31-45 please put a tick mark $(\sqrt{ })$ where appropriate in the box below. In learning English, how often do you do the following?

\begin{tabular}{|c|c|c|c|c|c|c|}
\hline \multirow[b]{2}{*}{ s.n } & \multirow{2}{*}{ Item } & \multicolumn{5}{|c|}{ Responses } \\
\hline & & 5 & 4 & 3 & 2 & \\
\hline 31 & I encourage students to judge their ability after they read books & & & & & \\
\hline 32 & I help learners to judge the quality of materials while they are reading & & & & & \\
\hline 33 & I advise learners to use English language reference books and other language learning materials & & & & & \\
\hline 34 & I help students to take the responsibility to outline a summary of reading text & & & & & \\
\hline 35 & $\begin{array}{l}\text { I advise learners to relate the skills they learned in reading lessons in dealing with extensive } \\
\text { / intensive reading }\end{array}$ & & & & & \\
\hline 36 & I let learners to take charge of taking the main idea/ points from lecture/ books & & & & & \\
\hline 37 & I counsel students to think about what they have learned in the language class & & & & & \\
\hline 38 & I encourage students to take diaries on their learning success and weakness & & & & & \\
\hline 39 & I help learners to evaluate the effectiveness of strategies they use to learn English & & & & & \\
\hline 40 & $\begin{array}{l}\text { I advise students to pay much attention to how well they understand a material they study } \\
\text { in learning Enqlish }\end{array}$ & & & & & \\
\hline 41 & I motivate students to analyze what difficulty I they actually have in learning English & & & & & \\
\hline 42 & I help students to set an action plan of how to solve learning problems or improve my learning & & & & & \\
\hline 44 & I encourage students to plan their schedule so that they will have enough time to study English & & & & & \\
\hline 45 & $\begin{array}{l}\text { After students have studied a piece of information in English, I encourage them to think about the way } \\
\text { thev have learned it }\end{array}$ & & & & & \\
\hline
\end{tabular}

Keys5=always4=usually3=sometimes2=rarely1=never

46. What does 'learner autonomy' or autonomous learning mean to you?

48. Do you think that learner autonomy is important? Why? Why, not?

49. Do you feel that learners should be responsible for decision making in the learning process?

Why? Why, not?

Questionnaire in Amharic for Students

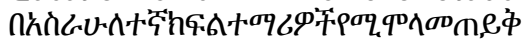

D.

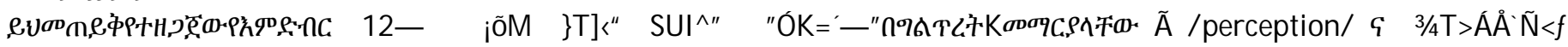

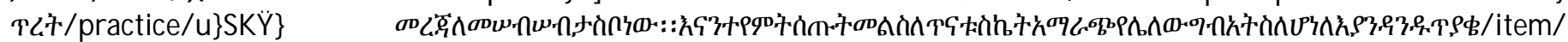

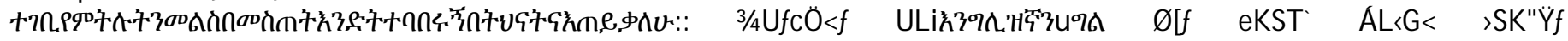

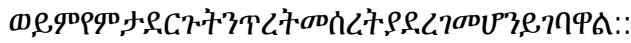

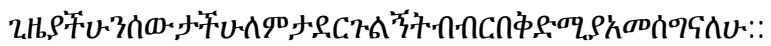

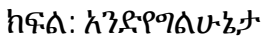

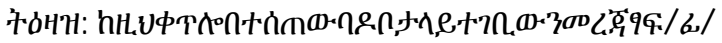

P: ถ่กไั่ว

hasulnt

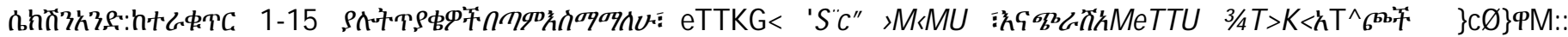

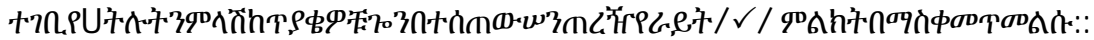




\begin{tabular}{|c|c|c|c|c|c|}
\hline \multirow[t]{2}{*}{$T+$} & \multirow[t]{2}{*}{$T \rho Q$} & \multicolumn{4}{|c|}{$\mathrm{ULj}<$} \\
\hline & & \begin{tabular}{|l|l|l}
5 & 4 \\
\end{tabular} & 3 & 2 & 1 \\
\hline 1 & 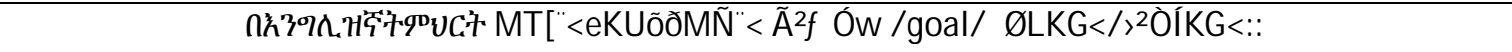 & & & & \\
\hline 2 & 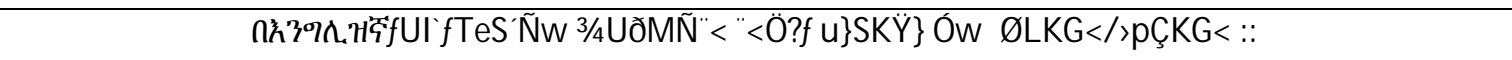 & & & & \\
\hline 3 & 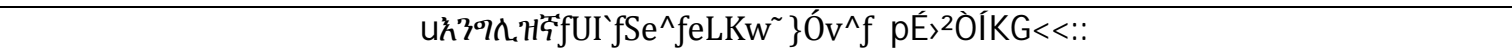 & & & & \\
\hline 4 & 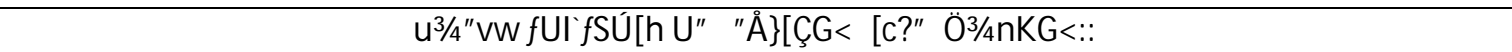 & & & & \\
\hline 5 & 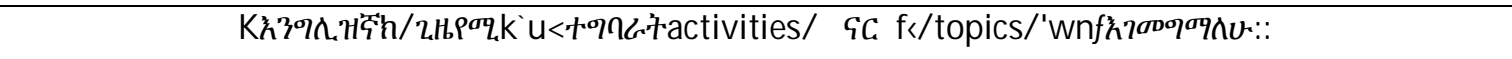 & & & & \\
\hline 6 & 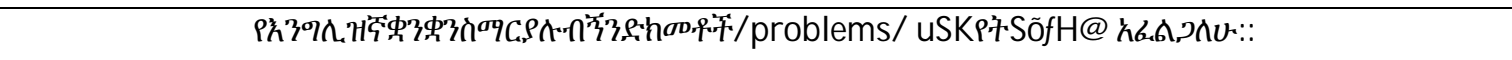 & & & & \\
\hline 7 & 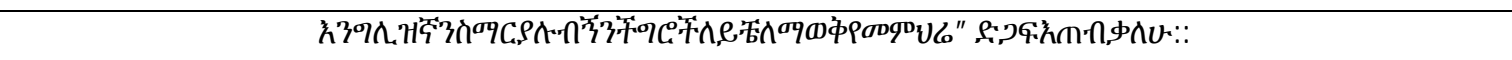 & & & & \\
\hline 8 & 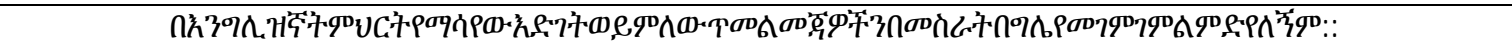 & & & & \\
\hline 9 & 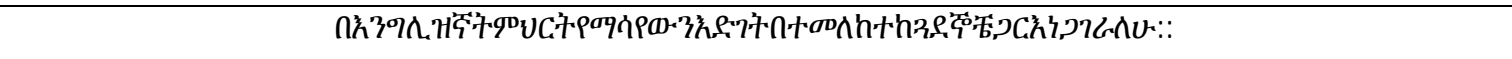 & & & & \\
\hline 10 & 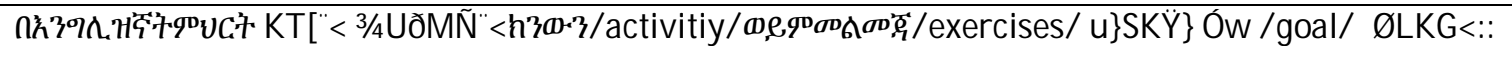 & & & & \\
\hline 11 & 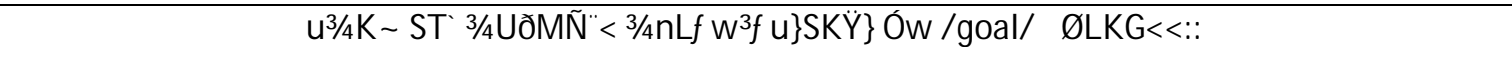 & & & & \\
\hline 12 & 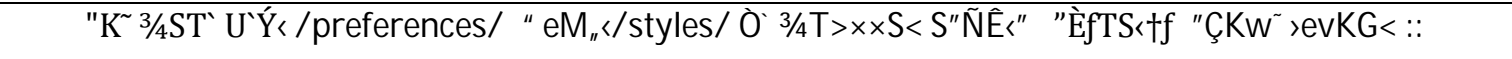 & & & & \\
\hline 13 & 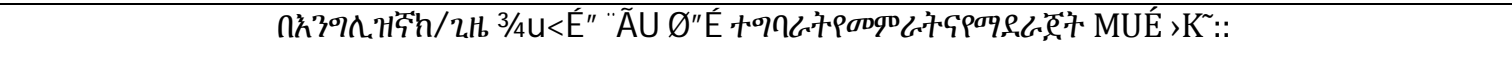 & & & & \\
\hline 14 & 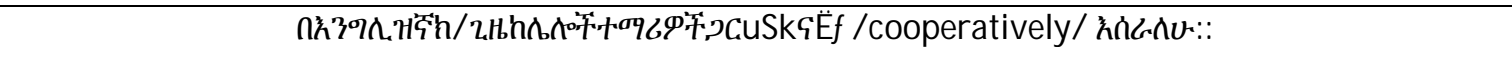 & & & & \\
\hline 15 & 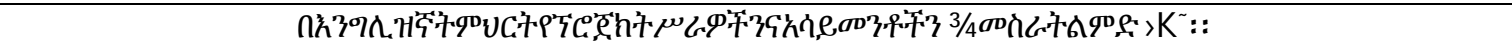 & & & & \\
\hline
\end{tabular}

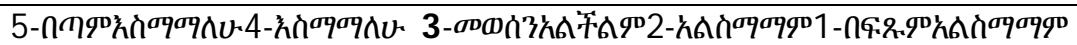

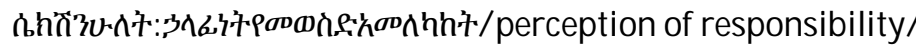

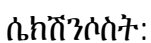

\begin{tabular}{|c|c|c|c|c|}
\hline t.\$. & 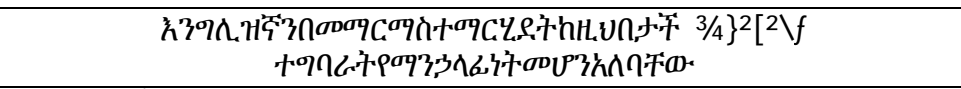 & 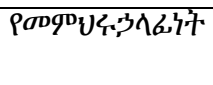 & 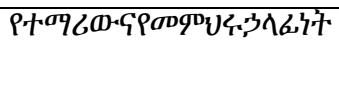 & 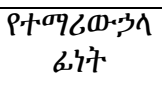 \\
\hline 16 & 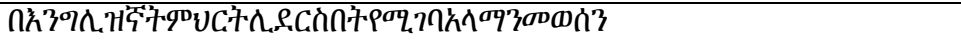 & & & \\
\hline 17 & 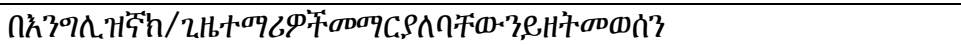 & & & \\
\hline 18 & 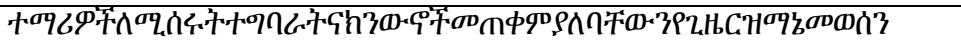 & & & \\
\hline 19 & 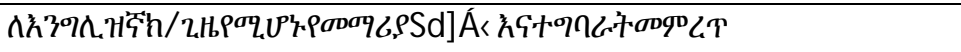 & & & \\
\hline 200 & 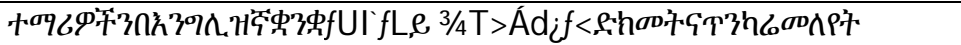 & & & \\
\hline 21 & 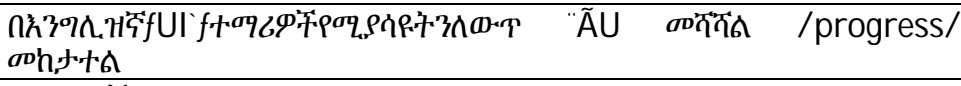 & & & \\
\hline 22 & 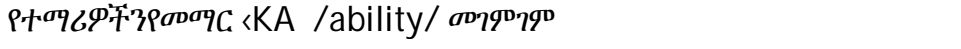 & & & \\
\hline 23 & 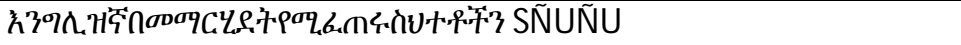 & & & \\
\hline
\end{tabular}

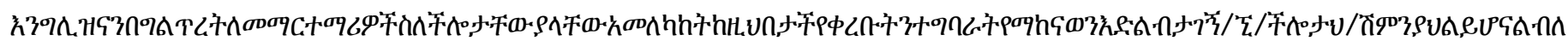

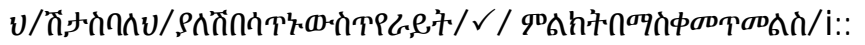

\begin{tabular}{|c|c|c|c|c|c|c|}
\hline \multirow[t]{2}{*}{ 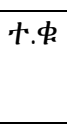 } & \multirow{2}{*}{ ר } & \multicolumn{5}{|c|}{ ULjT } \\
\hline & & 5 & 4 & 3 & 2 & 1 \\
\hline 24 & 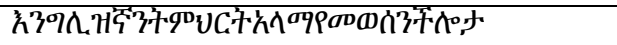 & & & & & \\
\hline
\end{tabular}




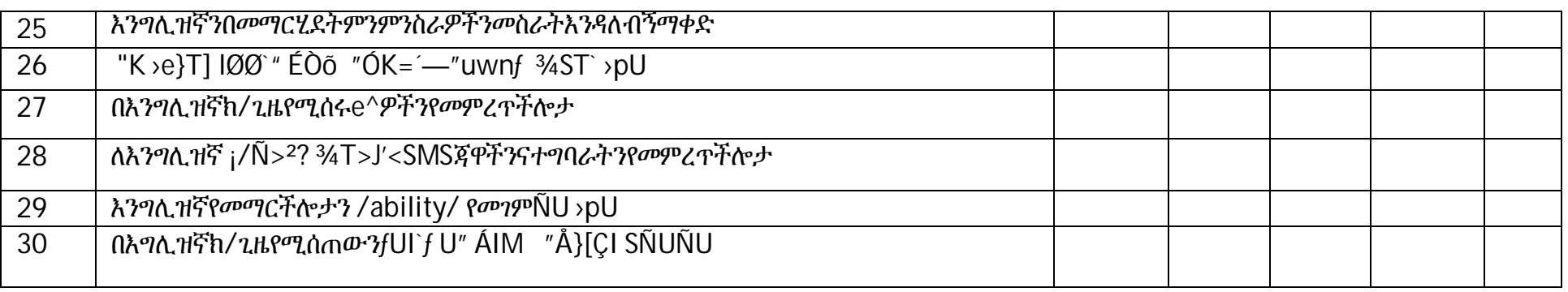

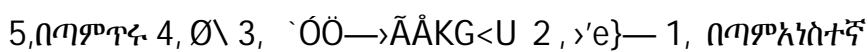

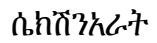

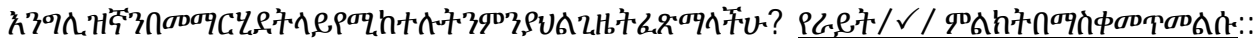

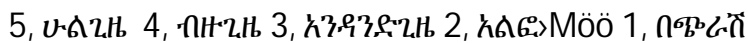

\begin{tabular}{|c|c|c|c|c|c|c|}
\hline \multirow[t]{2}{*}{ T中. } & \multirow[t]{2}{*}{$T S Q$} & \multicolumn{5}{|c|}{ ULj策 } \\
\hline & & 5 & 4 & 3 & 2 & 1 \\
\hline 31 & 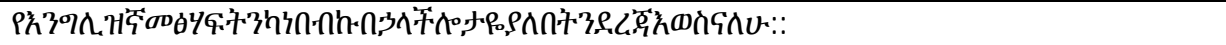 & & & & & \\
\hline 32 & 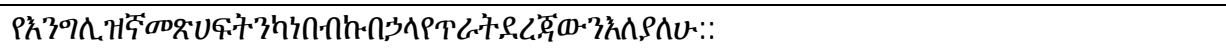 & & & & & \\
\hline 33 & 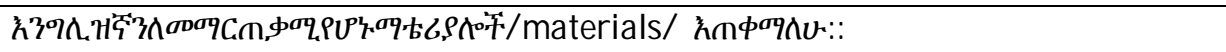 & & & & & \\
\hline 34 & 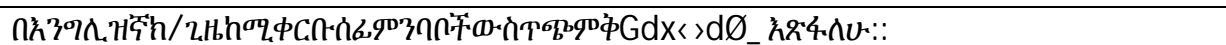 & & & & & \\
\hline 35 & 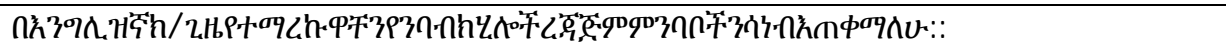 & & & & & \\
\hline 36 & 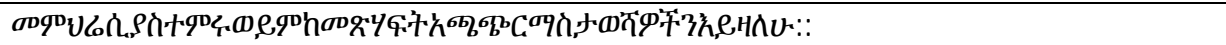 & & & & & \\
\hline 37 & 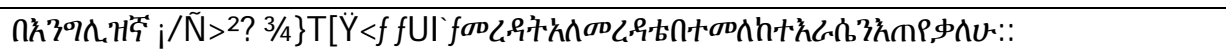 & & & & & \\
\hline 38 & 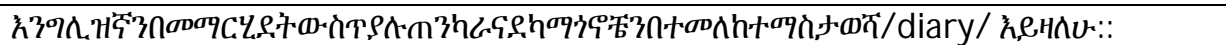 & & & & & \\
\hline 39 & 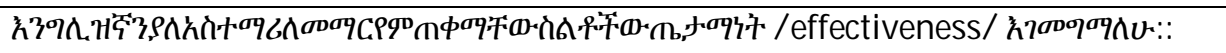 & & & & & \\
\hline 40 & 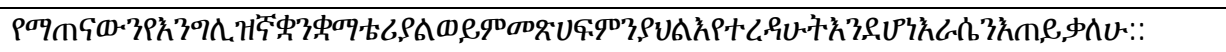 & & & & & \\
\hline 41 & 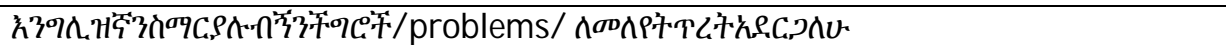 & & & & & \\
\hline 42 & 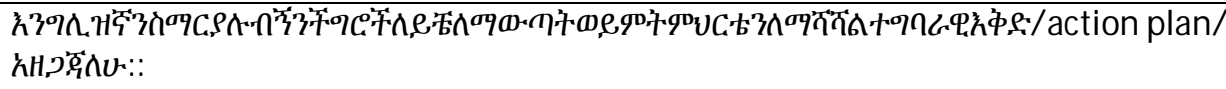 & & & & & \\
\hline 43 & 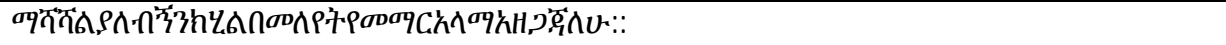 & & & & & \\
\hline 44 & 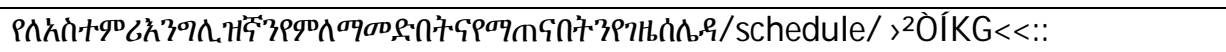 & & & & & \\
\hline 45 & 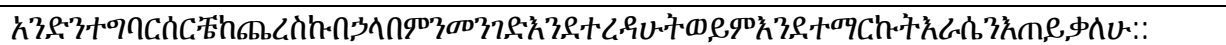 & & & & & \\
\hline
\end{tabular}

Verbatim Account of Interview with Students

Interviewer: I would like to thank for your willingness to attend this interview. The aim of this interview is to gather relevant information on the topic entitled 'Learner Autonomy in EFL Classroom: Perception and Practice. Grade Twelve 
Students and Teachers at Emdebir Preparatory School in Focus. I kindly request you to express your views and opinion based on your perceptions and practices. I promise that your responses will be kept with maximum confidentiality.

Interviewer:Do you want to involve or do autonomous learning activities such as assignments, project works, group and pair works if the teacher does not insistyou to do such activities?

Student A:"Well, I can do assignments and projects by myself. It is not good to work on my own. I like working with others. They are funny. We can help each other.".

Student B:"Yes, Itry to learn English with other students. I learn many things from my friends.

But I face difficulty knowing how much I have learned. It's interesting to see a

language task completed by myself".

Student C:"No, I want the teacher to do these activities. They are time taking. I like the teacher

to do the assignments and project works for us. I can learn more if I'm taught than learn by myself. Because group and pair works are noisy".

Student D:"No, I feel afraid of working with other students. But I think group and pair work

activities are important. They can help me learn independently."

Student E:"No, group works are boring. It is good for me to come to contact others. I want to

learn from the teacher. I don't think I can do project works by myself I have problem

to understand them."

Student F:"No, cooperative learning activities are effortful. They include problem solving

activities. I would like if teachers do the activities for us. I don't think students

can do these activities by themselves".

Interviewer: In learning English, do you need your teacher's help all the time? If no, in what

ways do you expect your teacher to support you?

Student A:"No, expecting my teacher to render me a help can lead me to be dependent. I need

help when it is difficult for me to comprehend a language".

Student B:"No, I only need my teacher's help when a language task which I have been working

is really difficult to fully accomplish by myself".

Student C:"No, I only need my teacher's help when I want to get a detailed explanation of a

language item".

Student D:"Yes, I want my teacher's help to explain to me what is in the text book. It is difficult for me to learn English by myself. I want my teacher to be beside me for support".

Student E:"Yes, the teacher should always be closer to me. I can learn better from my teacher than learn by myself".

Student F:"No, I only seek my teacher's help whenever I meet activities and tasks which I have not dealt with before".

Interviewer: Do you like to get involved in decision making concerning various aspects of the learning process?

Student A:"Yes I would like to get involved in decision making in regard to classroom activities, materials and objectives, but the teacher does not motivate us".

Student B:"Yes, but when we talk to teachers about the activities and materials, teachers say

that they know the best".

Student C:"No, my teacher takes on most of the responsibilities. He sets the objectives of the

lesson, chooses activities we learn".

Student D:"No, it's the teacher's responsibility to make such decisions. They are trained for

such activities".

Student E:"No, my role is learning. It's the teacher's responsibilities to make decisions for the

learning Process. They know better than me".

Student F:"No, we have no access to learning materials and activities to choose from".

Students' Interview in English

1. Do you involve or do autonomous learning activities such as assignments, projects, group and

pair works? If yes, what do students gain by involving in such activities?

2. In learning English, do you need your teacher's help all the time? If no, mention the situations

in which you need your teacher's help?

3. Do you get involved in decision making concerning various aspects of the learning process?

Probes

- Deciding on the objectives of the English lesson

- Deciding how to learn

- Deciding what to learn

4. How do you think about your ability to learn English autonomously? What are your views of learning English by yourself?

Probes

- $\quad$ Setting language learning goals

- Evaluating learning progress

- Identifying weaknesses and strengths in learning English 
Students' Interview in Amharic

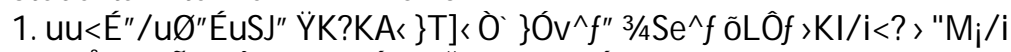

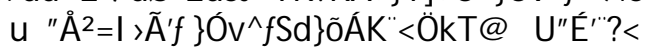

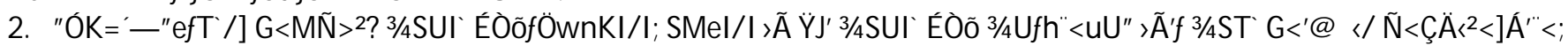

3. "ÓK='-" uST"H>Åf " $<d^{\prime} @$ uSeÖf H>Åf LÃ Sd \}õf"ÇKI/ ÍKi?;

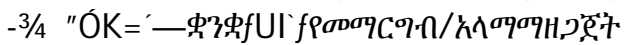

$-3 / 4 \mathrm{ST}^{\prime \prime} \mathrm{e}^{\prime \prime} \tilde{\mathrm{A}}^{2} \mathrm{fS}$ " c"

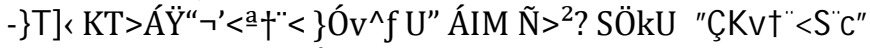

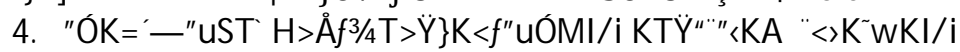

$\mathrm{U}$ 'KI/ - Ki;

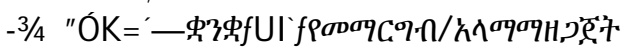

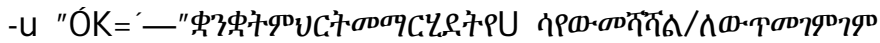

$-3 / 4$ "ÓK='-"

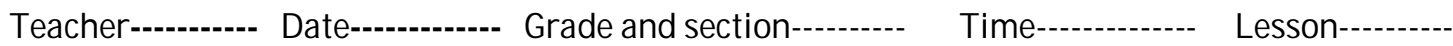

\begin{tabular}{|c|c|c|c|}
\hline s.n & Activities/Tasks & Yes & No \\
\hline \multirow[t]{5}{*}{1.} & Encourage learners to set some learning goals & & \\
\hline & Encourage learners to plan what tasks to do & & \\
\hline & Encourage goal setting on what skills to improve & & \\
\hline & Motivate students to plan the number of vocabularies to study & & \\
\hline & Encourage to set some task purposes & & \\
\hline \multirow[t]{5}{*}{2.} & Encourage responsibilities in collaborative work & & \\
\hline & Encourage learners to work in groups/ pairs & & \\
\hline & Help learners evaluate their group works & & \\
\hline & Encourage learners to manage the time for doing group works & & \\
\hline & Set project works/ assignments & & \\
\hline \multirow[t]{5}{*}{3.} & Involve learners in decision making & & \\
\hline & Encourage learners to choose activities and tasks they prefer to do & & \\
\hline & Encourages learners to choose someone to work with & & \\
\hline & $\begin{array}{l}\text { Let learners decide how to go about tasks and activities by providing help at the } \\
\text { outset }\end{array}$ & & \\
\hline & Respect learners' pace of learning & & \\
\hline \multirow[t]{5}{*}{4.} & Encourage self-evaluation & & \\
\hline & Encourage self-correction following the necessary feedback from the teacher & & \\
\hline & Allow peer-editing where necessary & & \\
\hline & Set follow-up questions in order to help learners think how much they have learned & & \\
\hline & Encourage learners to take learning diaries & & \\
\hline \multirow[t]{5}{*}{5} & Provide opportunity for strategy use & & \\
\hline & Encourage learners to ask questions & & \\
\hline & Let learners plan schedule for accomplishing tasks & & \\
\hline & Teach students learning strategies & & \\
\hline & Encourage learners to write summaries of information & & \\
\hline
\end{tabular}

Classroom Activities Observation Checklist 